\title{
Synthesis and biological evaluation of immunoconjugates of adriamycin and a human IgM linked by poly $\left[N^{5}-(2\right.$-hydroxyethyl)-L-glutamine ]
}

\author{
C.J.T. Hoes ${ }^{\text {a }}$, M. Ankoné ${ }^{\text {, }}$ J. Grootoonk ${ }^{\text {a }}$, J. Feijen ${ }^{\text {a,* }}$, E. van der Struik ${ }^{\text {, }}$, \\ A. van Doornmalen ${ }^{\text {b }}$, D. Pham ${ }^{\text {b }}$, A. de Man ${ }^{\text {b }}$, A. van Ettekoven ${ }^{\text {b }}$, I. Schlachter ${ }^{\text {b }}$, \\ P.J. Boon ${ }^{\text {b }, ~ F . ~ K a s p e r s e n ~}{ }^{\text {b }}$, E.S. Bos ${ }^{\text {b }}$ \\ ${ }^{a}$ Department of Chemical Technology, University of Twente. P.O. Box 217, 7500 AE Enschede. The Netherlands \\ ${ }^{6}$ N.V. Organon, P.O. Box 20,5340 BH Oss. The Netherlands
}

Received 5 November 1993; accepted 18 August 1995

\begin{abstract}
The synthesis and purification of radiolabelled immunoconjugates, composed of a human IgM monoclonal antibody (IgM 16.88 ) directed against an intracellular tumour-associated antigen, the drug carrier poly[ $N^{5}$-(2-hydroxyethyl)-L-glutamine] (PHEG) and the cytostatic drug adriamycin (ADR) are described. The immunoconjugates were constructed to allow selective release of ADR in the putatively acidic environment of the tumour through a novel acid-labile maleamic acid linker. The conjugate of PHEG and the acid-labile ADR derivative effectively released ADR in cytotoxic amounts at a pH of 6.0 as judged from incubation in buffer and from inhibition of the growth of HT-29 colon tumour cells in vitro. Immunoconjugates were prepared by coupling of PHEG-ADR having a hydrolytically stable amide bond with ${ }^{131}$ I-labelled antibody through thioether bond formation involving a single thiol group at the C-terminus of the polymer chain and maleimido groups introduced onto the

\footnotetext{
* Corresponding author.

Abbreviations: AcOSu, $N$-succinimidyl acetate; ADR, adriamycin; AEC, anion-exchange chromatography; ASI, active specific immunotherapy; BOC, tert-butoxycarbonyl; ( $\mathrm{BOC})_{2} \mathrm{O}$, di-tert-butyldicarbonate; BOC-AB, $N$-tert-butoxycarbonyl-1,4-diaminobutane; BOC-OEA, $N$-tert-butoxycarbonyl-2,2'-oxybis( ethylamine); $\mathrm{CDI}, N, N^{\prime}$-carbonyldiimidazole; $\mathrm{CHCl}_{3}$, chloroform; $\mathrm{CH}_{2} \mathrm{Cl}_{2}$, dichloromethane; CTA-1, colon tumourassociated antigen; Cys, cysteine; d, doublet; dd, double doublet; dt, double triplet; DAB, 3, $3^{\prime}$-aminobenzidine; DMF, $N, N^{\prime}$-dimethylformamide; DMSO, dimethylsulfoxide; $\mathrm{DP}_{n}$, number-average degree of polymerization; $\mathrm{DP}_{\mathrm{w}}$, weight-average degree of polymerization; DSS, 4,4-dimethyl4-silapentane sodium sulphonate; DTNB, 5,5'-dithiobis ( 2-nitrobenzoic acid); DTP, 4,4'-dithiodipyridine; DTT, dithiothreitol; $\varepsilon$, molar absorb-

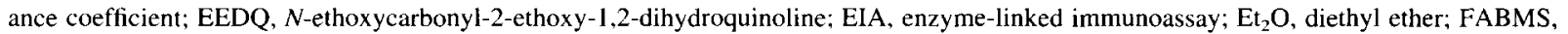
fast atom bombardment mass spectrometry: FCS, fetal calf serum; GABA, $\gamma$-aminobutyric acid; GMB, $\gamma$-maleimidobutyryl; GMBS, $N$ - $(\gamma-$ maleimidobutyryloxy) succinimide; HOAc, acetic acid; HONSu, $N$-hydroxysuccinimide; HPMA, $N$-(2-hydroxypropyl) methacrylamide; HP$M_{\mathrm{n}}$, number-average molecular weight; $M_{\mathrm{w}}$, weight-average molecular weight; MRW, mean residue weight; MoAb, monoclonal antibody; MSA, methanesulphonic acid; MTT, 3-( 4,5-dimethylthiazol-2-yl)-2,5-diphenyl tetrazolium bromide; $\mathrm{NaN}_{3}$, sodium azide; NCA, $N$-carboxyanhydride; PBLG, poly ( $\gamma$-benzyl-L-glutamate); PBS. phosphate-buffered saline; PDT, 2-pyridyldithio; PGA, poly ( $\alpha$-L-glutamate); PHEG, poly[ $N^{5}$-(2hydroxyethyl)-L-glutamine ]; PVDF, poly (vinylidene fluoride); q, quintet; s, singlet; SDS-PAGE, polyacrylamide gel electrophoresis in the presence of sodium dodecylsulphonate; TMS, tetramethylsilane; SATA, S-acetylthioacetyl; SEC, size exclusion chromatography; SMCC, succinimidyl 4-[ $\mathrm{N}$-maleimidomethyl ] cyclohexane-1-carboxylate: sulfo-SMCC, sulfosuccinimidyl 4-[ $N$-maleimidomethyl]cyclohexane-1-carboxylate; TEA, triethylamine; TFA, trifluoroacetic acid; TLC, thin-layer chromatography; TMB, 3,3',5,5'-tetramethylbenzidine
} SEC, high-performance size exclusion chromatography; HRP, horseradish peroxidase; LALLS, low-angle laser light scattering; m, multiplet:
\end{abstract}


antibody. The immunoreactivity of IgM-PHEG-ADR conjugate was almost fully preserved. Tumour uptake and biodistribution of ${ }^{125}$ I-labelled PHEG-ADR and of ${ }^{131}$ I-labelled IgM-PHEG-ADR, which was co-administered with ${ }^{3} \mathrm{H}-\mathrm{labelled}$ IgM 16.88 , in nude mice carrying MRI-H-207 human ovarian tumour xenografts were studied. ${ }^{125}$ I bound to PHEG-ADR was cleared relatively slowly from the circulation and significant tumour uptake was maintained during the period studied. The drug immunoconjugate was cleared more rapidly from the circulation with a concomitant decrease in tumour uptake as compared with unmodified IgM. The biodistribution data indicate that targeting of ADR with IgM 16.88 in this tumour model is not feasible.

Keywords: Adriamycin; Antibody: Biodegradable polymer; Drug targeting; Poly [ $N^{5}-(2$-hydroxyethyl $)$-L-glutamine $]$

\section{Introduction}

The targeting of drugs, radioisotopes and toxins with the aid of monoclonal antibodies (MoAbs) directed against tumour-associated antigens is an intensively studied strategy in the treatment of cancer [1-3]. Most studies in which repetitive administration of immunoconjugates of these MoAbs was applied were hampered by the development of a human anti-mouse antibody (HAMA) response [1]. Therefore, human MoAbs have become the antibodies of choice in our diagnostic and therapeutic studies [4-7]. These antibodies can be produced on a large scale and have been administered to humans in amounts up to $1 \mathrm{~g}$ without evoking an immune response or other undesirable side effects [6,7]. A human IgM designated 16.88 reacting with an intracellular cytokeratin-related tumour antigen [8] and homing to permeable cells in the tumour as shown by radio-imaging studies was used as targeting vehicle in our studies on the development of therapeutically active drug immunoconjugates.

As pointed out earlier [1], large amounts of chemoimmunoconjugates with a molar drug/antibody ratio of at least 50 are needed for an effective tumour regression if adriamycin (ADR) is employed as the cytostatic drug and the use of intermediate drug carriers [9] is a prerequisite in order to achieve the appropriate drug load of the immunoconjugate in case IgM antibodies are used as the targeting vehicle. We found previously that immunoconjugates of $\operatorname{IgM} 16.88$ and poly $\left[N^{5}-(2-\right.$ hydroxyethyl)-L-glutamine] (PHEG) show a biodistribution profile comparable with that of $\operatorname{IgM} 16.88$ per se $[10]$. We now have extended these studies to ADRcontaining immunoconjugates derived from IgM 16.88 and PHEG as the drug carrier. The preparation of conjugates of ADR and PHEG using a novel acid-labile linker based on a maleamic acid derivative and of immunoconjugates is described. By the use of these linkers the rate of drug release from conjugates in an acidic environment is faster by at least one order of magnitude as compared to that at neutral $\mathrm{pH}[11,12]$. The uncharged PHEG was chosen as the drug carrier to facilitate the purification of immunoconjugates by standard chromatographic techniques. The tumour uptake and biodistribution of ${ }^{125}$ I-labelled PHEG-ADR conjugate and of immunoconjugates consisting of ${ }^{131} I-$ labelled antibody and PHEG-ADR were investigated in nude mice carrying MRI-H-207 human ovarian tumour xenografts and were compared with the data of IgM 16.88. The results, in particular the in vivo effect of ADR present in immunoconjugates, are discussed in relation to the targeting of the free drug.

\section{Materials and methods}

\subsection{Materials}

The following compounds were obtained from the manufacturer indicated and were used as supplied. 2Aminoethanol, Merck, Germany; $N, N$-carbonyldiimidazole (CDI), Merck, Germany; dithiothreitol (DTT), Merck, Germany; 5,5'-dithio-bis (2-nitrobenzoic acid) (DTNB), Sigma, USA; 4,4'-dithiodipyridine (DTP), Sigma, USA; $N$-ethoxycarbonyl-2-ethoxy-1,2-dihydroquinoline (EEDQ), Serva, Germany; $N$ - $(\gamma$-maleimidobutyryloxy) succinimide, (GMBS), Sigma, USA and Fluka, Germany; $N$-succinimidyl acetate ( AcOSu), Sigma, USA; $N$-succinimidyl 4-[ $N$-maleimidomethyl]cyclohexane-1-carboxylate (SMCC), Pierce, USA; $N$-sulfosuccinimidyl 4 -[ $N$-maleimidomethyl]cyclohexane-1-carboxylate (sulfo-SMCC), Pierce, USA.

The human IgM MoAb 16.88 was provided by Organon Teknika/Biotechnology Research Institute, Rockville $M D$, USA. 
The following compounds were prepared as described. $\gamma$-Benzyl-L-glutamate (BLG 11) [13]; $\gamma$ benzyl-L-glutamate $N$-carboxyanhydride (BLG NCA 12) $[10]$; poly ( $\gamma$-benzyl-L-glutamate) containing cystamide groups ( $S_{2}$-PBLG 13a,b), a mixture of bis[poly ( $\gamma$-benzyl-L-glutamate)]cystamide (bisPBLG-cystamide 13a) and poly ( $\gamma$-benzyl- L-glutamate) (PBLG 13b) [10]; poly ( $\alpha$-L-glutamic acid) containing cystamide groups $\left(\mathrm{S}_{2}-\mathrm{PGA} \mathbf{1 4 a}, \mathrm{b}\right)$, a mixture of bis[poly ( $\alpha$-L-glutamic acid)]cystamide (bisPGA-cystamide 14a) and poly ( $\alpha$-L-glutamic acid) (PGA 14b) [10]; high-molecular weight PGA 14b [14]; cystamine free base from the dihydrochloride [15].

Buffers were prepared from analytical grade salts, filtered and deaerated with nitrogen. Buffer I, $50 \mathrm{mM}$ $\mathrm{Na}_{2} \mathrm{HPO}_{4} / \mathrm{H}_{3} \mathrm{PO}_{4}, 1$ mM EDTA, pH 7.5; buffer II, 0.10 $\mathrm{M} \mathrm{NaCl}, 10 \mathrm{mM} \mathrm{Na} 2 \mathrm{HPO}_{4} / \mathrm{H}_{3} \mathrm{PO}_{4}$, pH 7.0; buffer III, $0.10 \mathrm{M} \mathrm{NaCl}, 50 \mathrm{mM} \mathrm{NaH} \mathrm{PO}_{4} / \mathrm{Na}_{2} \mathrm{HPO}_{4}, 1 \mathrm{mM}$ EDTA, pH 6.0; buffer IV, $0.14 \mathrm{M} \mathrm{NaCl}, 25 \mathrm{mM}$ Tris $\cdot \mathrm{HCl}, \mathrm{pH} 8.0$; buffer $\mathrm{V}, 70 \mathrm{mM} \mathrm{NaCl}, 25 \mathrm{mM}$ Tris $\cdot \mathrm{HCl}, \mathrm{pH} 8.0$.

\subsection{Methods}

\section{Analytical procedures}

NMR spectra were recorded on Bruker instruments operating at 200 or $250 \mathrm{MHz}\left({ }^{1} \mathrm{H}\right)$ or $50 \mathrm{MHz}\left({ }^{13} \mathrm{C}\right)$. Chemical shifts $(\delta)$ are given in ppm relative to tetramethylsilane (TMS) or 4,4-dimethyl 4-silapentane sodium sulphonate (DSS). In order to replace exchangeable protons of water-soluble polymers by deuterons, a solution of the polymers in $\mathrm{D}_{2} \mathrm{O}(99.8 \%$ D) was left to stand at room temperature for $2-3 \mathrm{~h}$ and was then lyophilized. This procedure was repeated once, and spectra were recorded of solutions of the polymers in $\mathrm{D}_{2} \mathrm{O}(99.96 \% \mathrm{D})$. Thin-layer chromatography (TLC) was performed on silica coated onto plastic sheets $\mathrm{GF}_{254}$ (Merck, Germany) using the following solvent systems: A, toluene/ethanol $(8 / 2 ; v / v) ; B$, ethyl acetate/hexane $(1 / 1 ; \mathrm{v} / \mathrm{v}) ; \mathrm{C}, n$-butanol/acetic acid/water $(4 / 1 / 1 ; v / v)[10,14]$. Polyacrylamide gel electrophoresis (PAGE) in the presence of sodium dodecylsulphonate (SDS) was performed as described [10].

Samples for amino acid analysis were hydrolyzed in $5.8 \mathrm{~N} \mathrm{HCl}$ at $110^{\circ} \mathrm{C}$ for $48 \mathrm{~h}$. Hydrolyses and amino acid analyses were performed in duplicate. The content of polymer- or immunoconjugate-bound ADR was determined by quantification of $\beta$-Ala and Asp using amino acid analysis. The content of maleimido groups was determined by quantification of $\gamma$-aminobutyric acid using amino acid analysis. IgM concentrations were calculated from the absorbance at $280 \mathrm{~nm}$ using an absorbance value of 1.4 for a $1 \mathrm{mg} / \mathrm{ml}$ solution [ 10] . For ADR-containing immunoconjugates the IgM concentration was calculated from the absorbance at 280 $\mathrm{nm}$ after subtracting the contribution of ADR which was estimated from the absorbance at $490 \mathrm{~nm}$ and the known ratio of absorbancies at 280 and $490 \mathrm{~nm}$ of PHEG-ADR.

The concentration of thiol/disulfide groups bound to polymeric carrier or ADR conjugate was determined using DTNB [16] or DTP [17].

The concentration of polymer- or protein-bound maleimido groups was determined as follows. Solutions of maleimido-containing conjugate in buffer I (0.025-0.100 $\mathrm{ml}$ series, ca. $0.5-1 \mathrm{mM}$ maleimido groups $)$, Cys $(0.050 \mathrm{ml}, 2 \mathrm{mM}$ in water $)$ and buffer I (to give $1.10 \mathrm{ml}$ total assay volume) were mixed and the mixture was reacted for $10 \mathrm{~min}$ at room temperature. A mixture without conjugate was used as the standard. Then a solution of DTP $(0.100 \mathrm{ml} ; 2 \mathrm{mM})$ was added to each mixture and after $15 \mathrm{~min}$ the increase in absorbance at $328 \mathrm{~nm}$ was determined. The concentration of maleimido groups was calculated from the depletion in the concentration of Cys relative to the standard as measured by the Cys-mediated change in absorbance at $328 \mathrm{~nm}$ due to release of $4^{\prime}$-pyridinthione (molar absorbance coefficient $20800 \mathrm{M}^{-1} \mathrm{~cm}^{-1}$ ).

\section{Ultrafiltration and diafiltration}

Ultrafiltration and diafiltration of polymers or proteins were performed with Amicon stirred cells (400, 50 and $10 \mathrm{ml}$ ) using Amicon YM-10 membranes. Polymers were desalted by diafiltration with water until the conductivity of the ultrafiltrate was $10-15 \mu \mathrm{S}$, which required the addition of $6-8$ times the volume of water relative to sample volume.

\section{Characterization of polymers}

The weight-average and number-average molecular weights ( $M_{\mathrm{w}}$ and $M_{\mathrm{n}}$, respectively) of $\mathrm{S}_{2}-$ PBLG and PHEG copolymers were determined by high-performance size-exclusion (HP-SEC)/low-angle laser light scattering (LALLS) analysis. $\mathrm{S}_{2}-\mathrm{PBLG}$ was analyzed 
Table 1

Preparation of polymeric carriers and conjugates with $2,2^{\prime}$-oxybis (ethylamine) after polymerization of BLG NCA 12 in dioxane (4 wt\%) by cystamine (monomer/initiator ratio $48 \mathrm{~mol} / \mathrm{mol}$ )

\begin{tabular}{|c|c|c|c|c|c|c|c|}
\hline Polymer & Yield $(\%)$ & $M_{\mathrm{w}}\left(\times 10^{-4}\right)$ & $\mathrm{DP}_{\mathrm{w}}$ & $M_{\mathrm{n}}\left(\times 10^{-4}\right)$ & $\mathrm{DP}_{\mathrm{n}}$ & $M_{\mathrm{w}} / M_{\mathrm{n}}$ & $\mathrm{d} n / \mathrm{d} c(\mathrm{ml} / \mathrm{g})$ \\
\hline 13a,b $S_{2}-$ PBLG-I & $93^{\mathrm{c}}$ & $3.15^{h}$ & $144^{\mathrm{h}}$ & $2.18^{\mathrm{h}}$ & $100^{\mathrm{h}}$ & 1.44 & 0.1127 \\
\hline 13a,b S S $_{2}$ PBLG-II & $83^{c}$ & $4.55^{\mathrm{h}}$ & $208^{\mathrm{h}}$ & $3.18^{\mathrm{h}}$ & $145^{\mathrm{h}}$ & 1.43 & 0.1169 \\
\hline 13a,b S S $_{2}$ PBLG-III & $88^{\circ}$ & $4.90^{\mathrm{h}}$ & $223^{\mathrm{h}}$ & $3.59^{h}$ & $164^{\mathrm{h}}$ & 1.36 & 0.1070 \\
\hline $14 a, b S_{2}-P G A-I^{a}$ & $71^{\mathrm{d}}$ & $1.94^{\mathrm{j}}$ & $150^{\mathrm{j}}$ & - & - & - & - \\
\hline $14 a, b S_{2}-P G A-I I I-1^{a}$ & $60^{\mathrm{d}}$ & $2.11^{\mathrm{j}}$ & $164^{j}$ & - & - & - & - \\
\hline 14a,b S $S_{2}-P G A-I I I-2^{a}$ & $62^{\mathrm{d}}$ & $2.49^{j}$ & $193^{j}$ & - & - & - & - \\
\hline 15a,b $S_{2}-P G A-O E A-B O C^{b}$ & $82^{\circ}$ & - & - & - & - & - & - \\
\hline 16a,b $S_{2}$-PHEG-OEA-BOC & $93^{f}$ & $6.76^{\mathrm{k}, \mathrm{m}}$ & $368^{\mathrm{k} \cdot \mathrm{m}}$ & $5.11^{\mathrm{k} . \mathrm{m}}$ & $278^{\mathrm{k} \cdot \mathrm{m}}$ & 1.32 & 0.1565 \\
\hline $17 \mathbf{a}, \mathbf{b} S_{2}$-PHEG-OEA-NH ${ }_{2}$ crude $^{\mathrm{b}}$ & $78^{r}$ & $6.66^{\mathrm{k} . \mathrm{m}}$ & $378^{\mathrm{k} \cdot \mathrm{m}}$ & $5.70^{\mathrm{k} . \mathrm{m}}$ & $324^{k . m}$ & 1.17 & 0.1556 \\
\hline 17a,b S $\mathrm{S}_{2}$-PHEG-OEA-NH $\mathrm{NH}_{2} \mathrm{HMW}^{\mathrm{b}}$ & - & $7.46^{\mathrm{k.m}}$ & $423^{\mathrm{k} \cdot \mathrm{m}}$ & $6.54^{k . m}$ & $371^{\mathrm{k} \cdot \mathrm{m}}$ & 1.14 & 0.1651 \\
\hline 17a,b $S_{2}$-PHEG-OEA-NH ${ }_{2}$ LMW $^{b}$ & $42^{\mathrm{g}}$ & $4.22^{\mathrm{k}, \mathrm{m}}$ & $239^{\mathrm{k} \cdot \mathrm{m}}$ & $3.98^{k, m}$ & $226^{\mathrm{k}, \mathrm{ml}}$ & 1.06 & 0.1557 \\
\hline
\end{tabular}

${ }^{a}$ Amount of residual benzyl groups $0.5 \mathrm{~mol} \%$.

'Prepared from 14a,b batch II.

'Relative to 12.

${ }^{\mathrm{d}}$ Relative to 13a,b.

'Relative to $14 a, b$.

'Relative to previous conjugate.

"Average value relative to crude conjugate.

"By HP-SEC/LALLS in DMF

${ }^{\mathrm{i}}$ By viscometry.

${ }^{k}$ Apparent value, see section 3 .

"'By HP-SEC/LALLS in 0.1 M sodium acetate, pH 6.0.

as described [10]. PHEG copolymers were analyzed using three TSK columns (G $5000 \mathrm{PW}, \mathrm{G} 4000 \mathrm{PW}$, G $3000 \mathrm{PW})(7.8 \times 300 \mathrm{~mm})$ in series equilibrated in $0.1 \mathrm{M}$ sodium acetate, $\mathrm{pH} 6.0$, at a flow rate of $1.0 \mathrm{ml} /$ min. Refractive index increments $(\mathrm{d} n / \mathrm{d} c)$ at $633 \mathrm{~nm}$ of the polymers in the corresponding solvents are given in Table 1. The weight-average molecular weight $\left(M_{\mathrm{w}}\right)$ of $\mathrm{S}_{2}$-PGA was determined by viscometry $[10]$.

\section{Western blot of SDS-polyacrylamide gels}

Proteins were transferred from the gel onto poly(vinylidene fluoride) (PVDF) membranes by electrophoresis in a Transblot cell (Biorad, USA) using $25 \mathrm{mM}$ Tris $\cdot \mathrm{HCl}, 0.192 \mathrm{M}$ glycine, $200 \mathrm{ml} / 1$ methanol, $300 \mathrm{mg} / \mathrm{l}$ SDS as transfer buffer [ 18]. Blotting was carried out for $2 \mathrm{~h}$ at $10 \mathrm{~V} / \mathrm{cm}$ and $0.25 \mathrm{~A}$ at ambient temperature, the membrane being placed at the anodal side of the gel. The blot was then treated with Blotto ( $50 \mathrm{~g} / 1$ Skim milk, dehydrated, in phosphatebuffered saline (PBS) / Tween) for $2 \mathrm{~h}$ at $37^{\circ} \mathrm{C}$, washed with PBS/Tween and incubated with peroxidaselinked goat anti-human IgM in PBS $(1 \mathrm{mg} / \mathrm{ml}$ diluted 1:16000) for $1 \mathrm{~h}$ at $37^{\circ} \mathrm{C}$. After 3-fold washing with
PBS/Tween the IgM bands were visualized by a solution containing cobalt chloride $(0.6 \mathrm{~g} / 1)$, 3,3'-diaminobenzidine (DAB) $(0.3 \mathrm{~g} / \mathrm{l})$ and hydrogen peroxide $(0.03 \mathrm{~g} / 1)$ in PBS. The reaction was stopped by soaking in water.

\section{Synthetic procedures}

\section{2-(2-N-tert-Butoxycarbonylaminoethoxy)ethanol 2}

2-(2-Aminoethoxy) ethanol $1(7.5 \mathrm{~g}, 71.3 \mathrm{mmol})$ was dissolved in dichloromethane $\left(\mathrm{CH}_{2} \mathrm{Cl}_{2}\right)(50 \mathrm{ml})$ in a $250 \mathrm{ml}$ round-bottomed flask equipped with a magnetic stirrer and a pressure-equalizing addition funnel. A solution of di-tert-butyldicarbonate $\left((\mathrm{BOC})_{2} \mathrm{O}\right)$ (16.8 g, $77.0 \mathrm{mmol})$ in dichloromethane $\left(\mathrm{CH}_{2} \mathrm{Cl}_{2}\right)$ ( $50 \mathrm{ml}$ ) was added dropwise over $30 \mathrm{~min}$. After stirring for $3 \mathrm{~h}$ at room temperature the solution was diluted with diethyl ether $\left(\mathrm{Et}_{2} \mathrm{O}\right)(100 \mathrm{ml})$ and washed with sodium phosphate buffer $(0.5 \mathrm{M}, \mathrm{pH} 5.4,2 \times 50 \mathrm{ml})$, $5 \% \mathrm{NaHCO}_{3}(2 \times 50 \mathrm{ml})$ and saturated $\mathrm{NaCl}$ solution $(50 \mathrm{ml})$. The solution was dried $\left(\mathrm{Na}_{2} \mathrm{SO}_{4}\right)$, filtered and evaporated to dryness to give $\mathbf{2}$ as an oil. Yield $14.7 \mathrm{~g}(100 \%)$. TLC $R_{\mathrm{f}}$ (A) $0.56 ;{ }^{1} \mathrm{H}-\mathrm{NMR}\left(\mathrm{CDCl}_{3} /\right.$ 
TMS $): \delta=1.46 \quad(\mathrm{~s}, 9 \mathrm{H}, \mathrm{BOC}) ; 3.34(\mathrm{~m}, 2 \mathrm{H}$, $\left.\mathrm{BOCNHCH}_{2^{-}}\right) ; 3.55\left(\mathrm{t}, 2 \mathrm{H},-\mathrm{OCH}_{2^{-}}\right) ; 3.56(\mathrm{t}, 2 \mathrm{H}$, $\left.\mathrm{CH}_{2} \mathrm{O}-\right) ; 3.74\left(\mathrm{~m}, 2 \mathrm{H},-\underline{\mathrm{CH}}_{2} \mathrm{OH}\right)$.

\section{1-Azido-2-(2-N-tert-butoxycarbonylaminoethoxy)- ethane 3}

To a stirred and precooled $\left(0^{\circ} \mathrm{C}\right)$ solution of $2(14.7$ $\mathrm{g}, 71.3 \mathrm{mmol})$ and triethylamine (TEA) $(10 \mathrm{ml}, 71.6$ $\mathrm{mmol})$ in toluene $(200 \mathrm{ml})$ was added methanesulfonyl chloride $(5.52 \mathrm{ml}, 71.3 \mathrm{mmol})$ in an atmosphere of nitrogen. After 5 min tetrabutylammonium bromide $(2.3 \mathrm{~g}, 7.13 \mathrm{mmol})$ and a solution of sodium azide $\left(\mathrm{NaN}_{3}\right)(38.8 \mathrm{~g}, 0.60 \mathrm{~mol})$ in water $(150 \mathrm{ml})$ were added and the mixture was heated at $60^{\circ} \mathrm{C}$ for $3 \mathrm{~h}$. The mixture was allowed to cool to room temperature, diluted with $\mathrm{Et}_{2} \mathrm{O}(100 \mathrm{ml})$ and washed with sodium phosphate buffer $(0.5 \mathrm{M}, \mathrm{pH} 5.4,50 \mathrm{ml})$ and saturated $\mathrm{NaCl}$ solution $(50 \mathrm{ml})$. The solution was dried $\left(\mathrm{Na}_{2} \mathrm{SO}_{4}\right)$, filtered and evaporated to dryness to give 3 as an oil. Yield $14.15 \mathrm{~g}(85.9 \%)$. TLC $R_{\mathrm{f}}$ (B) 0.71 ; 'H-NMR ( $\left.\mathrm{CDCl}_{3} / \mathrm{TMS}\right): \delta=1.45(\mathrm{~s}, 9 \mathrm{H}, \mathrm{BOC}) ; 3.35$ $\left(\mathrm{m}, 2 \mathrm{H}, \mathrm{BOCNHCH}{ }_{2}\right) ; 3.40\left(\mathrm{t}, 2 \mathrm{H},-\mathrm{CH}_{2} \mathrm{~N}_{3}\right) ; 3.55$ $\left(\mathrm{t}, 2 \mathrm{H},-\mathrm{CH}_{2} \mathrm{O}-\right) ; 3.65\left(\mathrm{~m}, 2 \mathrm{H},-\mathrm{OCH}_{2}^{-}\right)$.

\section{$N$-tert-Butoxycarbonyl-2,2'-oxybis(ethylamine) hydrochloride (BOC-OEA 4)}

A solution of compound $3(14.15 \mathrm{~g}, 61.4 \mathrm{mmol})$ in a mixture of methanol $(\mathrm{MeOH})(200 \mathrm{ml})$ and chloroform $\left(\mathrm{CHCl}_{3}\right)(14 \mathrm{ml})$ was hydrogenated in the presence of $10 \% \mathrm{Pd} / \mathrm{C}(1.4 \mathrm{~g})$ for $1 \mathrm{~h}$. The catalyst was removed by filtration using hyflo, the hyflo was washed with additional $\mathrm{MeOH}(50 \mathrm{ml})$ and the combined filtrates were evaporated to dryness. The solid residue was triturated with $\mathrm{Et}_{2} \mathrm{O}(100 \mathrm{ml})$ and the precipitate 4 was isolated by filtration in a yield of 10.25 g $(69.3 \%)$. TLC $R_{\mathrm{f}}(\mathrm{C}) 0.58$; m.p. $104-110^{\circ} \mathrm{C} ;{ }^{1} \mathrm{H}-$ NMR ( $\left.\mathrm{D}_{2} \mathrm{O} / \mathrm{DSS}\right) ; \delta=1.44(\mathrm{~s}, 9 \mathrm{H}, \mathrm{BOC}) ; 3.20(\mathrm{dt}$, $\left.2 \mathrm{H},-\mathrm{CH}_{2} \mathrm{NH}_{2}\right) ; 3.30\left(\mathrm{t}, 2 \mathrm{H}, \mathrm{BOCNHCH} 2^{-}\right) ; 3.61(\mathrm{t}$, $\left.2 \mathrm{H},-\mathrm{OC}_{2}\right)$; $3.76\left(\mathrm{t}, 2 \mathrm{H},-\mathrm{CH}_{2} \mathrm{O}-\overline{-}\right) .{ }^{13} \mathrm{C}-\mathrm{NMR}$ $\left(\mathrm{D}_{2} \mathrm{O} / \mathrm{DSS}\right): \delta=30.405\left(\mathrm{q},-\left(\mathrm{CH}_{3}\right)_{3}\right) ; 41.892(\mathrm{t}$, $\left.-\mathrm{CH}_{2} \mathrm{NH}_{2}\right) ; 42.462$ (t, $\left.\mathrm{BOCNHCH}_{2}-\right) ; 68.971$ (t, $\left.-\mathrm{CH}_{2} \mathrm{O}-\right) ; 72.426 \quad\left(\mathrm{t},-\mathrm{OCH}_{2^{-}}\right) ; 83.906 \quad(\mathrm{~s}$, $\left.-\mathrm{C}\left(\mathrm{CH}_{3}\right)_{3}\right) ; \delta 161.094$ (s, -OCONH-). IR ( $\left.\mathrm{KBr}\right)$ : $3365,1688,1530,1175,1110 \mathrm{~cm}^{-1}$. Fast atom bombardment mass spectrometry (FABMS) (glycerol): $m / z 205.2[\mathrm{M}+\mathrm{H}]^{+} ; \mathrm{C}_{9} \mathrm{H}_{20} \mathrm{~N}_{2} \mathrm{O}_{3}$ requires 204.73 .
4-(N-tert-Butoxycarbonylamino)-1-butanol 6

4-Amino-1-butanol 5 (7.5 g, $84.1 \mathrm{mmol})$ was dissolved in $\mathrm{CH}_{2} \mathrm{Cl}_{2}(50 \mathrm{ml})$ in a $250 \mathrm{ml}$ round-bottomed flask equipped with a magnetic stirrer and a pressure-equalizing addition funnel. A solution of (BOC) ${ }_{2} \mathrm{O}$ (19.8 g, $\left.90.7 \mathrm{mmol}\right)$ in $\mathrm{CH}_{2} \mathrm{Cl}_{2}(50 \mathrm{ml})$ was added dropwise over $30 \mathrm{~min}$. After stirring for $3 \mathrm{~h}$ at room temperature the solution was diluted with $\mathrm{Et}_{2} \mathrm{O}$ $(100 \mathrm{ml})$ and washed with sodium phosphate buffer $(0.5 \mathrm{M}, \mathrm{pH} 5.4,2 \times 50 \mathrm{ml}), 5 \% \mathrm{NaHCO}_{3}(2 \times 50 \mathrm{ml})$ and saturated $\mathrm{NaCl}$ solution $(50 \mathrm{ml})$. The solution was dried $\left(\mathrm{Na}_{2} \mathrm{SO}_{4}\right)$, filtered and evaporated to dryness to give 6 as an oil. Yield $15.9 \mathrm{~g}(100 \%)$. TLC $R_{\mathrm{f}}(\mathrm{A})$ $0.59 ;{ }^{1} \mathrm{H}-\mathrm{NMR} \quad\left(\mathrm{CDCl}_{3} / \mathrm{TMS}\right): \delta=1.44(\mathrm{~s}, 9 \mathrm{H}$, BOC); $1.59\left(\mathrm{~m}, 4 \mathrm{H},-\mathrm{CH}_{2} \mathrm{CH}_{2}\right) ; 3.15$ (q, 2H, $\left.\mathrm{BOCNHCH}_{2}{ }^{-}\right) ; 3.67$ (q, 22 $\left.\overline{\mathrm{H},}-\overline{\mathrm{CH}}_{2} \mathrm{OH}\right)$.

\section{1-Azido-4-(N-tert-butoxycarbonylamino)butane 7}

To a stirred and precooled $\left(0^{\circ} \mathrm{C}\right)$ solution of 6 ( 15.9 $\mathrm{g}, 84.1 \mathrm{mmol})$ and TEA ( $12 \mathrm{ml}, 84.1 \mathrm{mmol})$ in toluene $(200 \mathrm{ml})$ was added methanesulfonyl chloride $(9.64$ $\mathrm{ml}, 84.1 \mathrm{mmol}$ ) in an atmosphere of nitrogen. After 5 min tetrabutylammonium bromide $(2.71 \mathrm{~g}, 8.41$ mmol) and a solution of $\mathrm{NaN}_{3}(45.7 \mathrm{~g}, 0.70 \mathrm{~mol})$ in water $(150 \mathrm{ml})$ were added and the mixture was heated at $60^{\circ} \mathrm{C}$ for $3 \mathrm{~h}$. The mixture was allowed to cool to room temperature, diluted with $\mathrm{Et}_{2} \mathrm{O}(100 \mathrm{ml})$ and washed with sodium phosphate buffer $(0.5 \mathrm{M}, \mathrm{pH} 5.4$, $50 \mathrm{ml}$ ) and saturated $\mathrm{NaCl}$ solution $(50 \mathrm{ml})$. The solution was dried $\left(\mathrm{Na}_{2} \mathrm{SO}_{4}\right)$, filtered and evaporated to dryness to give 7 as an oil. Yield $18.12 \mathrm{~g}(100 \%)$. TLC $R_{\mathrm{f}}$ (B) $0.59 ;{ }^{1} \mathrm{H}-\mathrm{NMR}\left(\mathrm{CDCl}_{3} / \mathrm{TMS}\right): \delta=1.45(\mathrm{~s}$, $9 \mathrm{H}, \mathrm{BOC}) ; 1.60\left(\mathrm{~m}, 4 \mathrm{H},-\mathrm{CH}_{2} \mathrm{CH}_{2}\right) ; 3.15(\mathrm{q}, 2 \mathrm{H}$, BOCNHCH $\left.2_{2}^{-}\right) ; 3.30\left(\mathrm{t}, 2 \mathrm{H},-\mathrm{CH}_{2} \overline{\mathrm{N}}_{3}\right)$.

$N$-tert-Butoxycarbonyl-1,4-diaminobutane hydrochloride ( $B O C-A B$ 8)

A solution of compound $7(18.12 \mathrm{~g}, 84.1 \mathrm{mmol})$ in a mixture of $\mathrm{MeOH}(200 \mathrm{ml})$ and $\mathrm{CHCl}_{3}(18 \mathrm{ml})$ was hydrogenated in the presence of $10 \% \mathrm{Pd} / \mathrm{C}(1.8 \mathrm{~g})$ for $1 \mathrm{~h}$. The catalyst was removed by filtration using hyflo, the hyflo was washed with additional $\mathrm{MeOH}(50 \mathrm{ml})$ and the combined filtrates were evaporated to dryness. The solid residue was triturated with $\mathrm{Et}_{2} \mathrm{O}(100 \mathrm{ml})$ and the precipitate 8 was isolated by filtration in a yield of $12.45 \mathrm{~g}(65.5 \%)$. TLC: $R_{\mathrm{f}}$ (C) $0.64 ;$ m.p. 149 $153^{\circ} \mathrm{C}\left(147-148^{\circ} \mathrm{C}[19]\right) ;{ }^{1} \mathrm{H}-\mathrm{NMR}\left(\mathrm{D}_{2} \mathrm{O} / \mathrm{DSS}\right)$ : $\delta=1.44 \quad(\mathrm{~s}, \quad 9 \mathrm{H}, \quad$ BOC $) ; 1.50-1.75 \quad(\mathrm{~m}, 4 \mathrm{H}$, 
$\left.-\mathrm{CH}_{2} \mathrm{CH}_{2}-\right) ; 3.03\left(\mathrm{t}, 2 \mathrm{H},-\mathrm{CH}_{2} \mathrm{NH}_{2}\right) ; 3.12(\mathrm{t}, 2 \mathrm{H}$, BOCNHCH $\left.2^{-}\right) \cdot{ }^{13} \mathrm{C}-\mathrm{NMR}\left(\mathrm{D}_{2} \overline{\mathrm{O}} / \mathrm{DSS}\right): \delta=26.805(\mathrm{t}$, $\left.\mathrm{NHCH}_{2} \underline{\mathrm{CH}} \overline{\mathrm{H}}_{2}^{-}\right) ; 28.774\left(\mathrm{t},-\underline{\mathrm{CH}} \mathrm{CH}_{2} \mathrm{NH}_{2}\right) ; 30.412$ $\left(\mathrm{q},-\left(\mathrm{CH}_{3}\right)_{3}\right) ; 41.904 \quad\left(\mathrm{t},-\mathrm{CH}_{2} \mathrm{NH}_{2}\right.$ and $\mathrm{t}$, $\left.\mathrm{BOCNHCH}_{2^{-}}\right) ; \quad 83.715\left(\mathrm{~s},-\mathrm{C}\left(\mathrm{CH}_{3}\right)_{3}\right) ; \quad 161.070$ (s, -OCONH-). IR (KBr): $3362,1689,1530,1175$ $\mathrm{cm}^{-1}$. FABMS (glycerol): $m / z \quad 189.2[\mathrm{M}+\mathrm{H}]^{+}$; $\mathrm{C}_{9} \mathrm{H}_{20} \mathrm{~N}_{2} \mathrm{O}_{2}$ requires 188.27 .

\section{$A D R$ derivatives 9 and 10}

The ADR derivatives $S$-acetylthioacetyl- $\beta$-Ala-AspADR (SATA- $\beta$-Ala-Asp-ADR 9) and $S$-acetylthioacetyl- $\beta$-Ala- $\beta$-methyl,dehydroAsp-ADR (SATA$\beta$-Ala- $\beta$-methyl,dehydroAsp-ADR 10) $[11,12]$ will be described in detail elsewhere [20].

Conjugate of $S_{2}-P G A \quad 14 a, b$ and $N$-tert-butoxycarbonyl-2,2'-oxybis(ethylamine) 4 ( $S_{2}-P G A-O E A-B O C$ $15 a, b)$

To a stirred solution of $\mathbf{1 4 a}, \mathrm{b}$ batch II, H-form ( 5.50 $\mathrm{g}, 42.6 \mathrm{mmol})$ in DMF $(120 \mathrm{ml}) 4(1.026 \mathrm{~g}, 4.26$ $\mathrm{mmol})$, TEA ( $0.594 \mathrm{ml}, 4.26 \mathrm{mmol})$ and a solution of $\operatorname{EEDQ}(1.264 \mathrm{~g}, 5.11 \mathrm{mmol})$ in DMF $(10 \mathrm{ml})$ were successively added and the mixture was stirred for 3 days at room temperature. The mixture was dissolved in $0.2 \mathrm{M}$ sodium phosphate buffer, $\mathrm{pH} 7.5(700 \mathrm{ml})$ and filtered $(0.2 \mu \mathrm{m})$. The solution was dialyzed against $0.2 \mathrm{M} \mathrm{NaCl}(1 \times 201)$ and water $(4 \times 201)$ at $4^{\circ} \mathrm{C}$ and was finally lyophilized. Yield $6.52 \mathrm{~g} \mathrm{(39.3}$ mmol, $92 \%)$ of 15a,b, sodium salt. ${ }^{1} \mathrm{H}-\mathrm{NMR}\left(\mathrm{D}_{2} \mathrm{O}\right)$ : $\delta=1.40$ (s, $8.89 \mathrm{~mol} \%$ of $9 \mathrm{H}$ relative to Glu, $\left.\left(\mathrm{CH}_{3}\right)_{3}\right) ; 2.00,\left(\mathrm{~m}, 2 \mathrm{H}\right.$, Glu $\left.\beta-\mathrm{CH}_{2}\right) ; 2.33(\mathrm{~m}, 2 \mathrm{H}$, Glu $\left.\gamma-\mathrm{CH}_{2}\right) ; 3.24(\mathrm{t}), 3.38($ broad s) and $3.58(\mathrm{~m})$ (8.91 mol\% of $8 \mathrm{H}$ relative to $\mathrm{Glu},-\underline{\mathrm{CH}}_{2} \underline{\mathrm{CH}}_{2}-$ $\mathrm{OCH}_{2} \underline{\mathrm{CH}}_{2^{-}}$); 4.33 (s, $1 \mathrm{H}$, Glu $\alpha-\mathrm{CH}_{2}$ ).

A solution of the polymer in water $(300 \mathrm{ml})$ was slowly poured into $0.1 \mathrm{~N} \mathrm{HCl}(500 \mathrm{ml})$ under vigorous stirring. The precipitate was isolated by centrifugation ( $3000 \mathrm{rpm}, 8 \mathrm{~min}$ ) and was resuspended in $0.01 \mathrm{~N} \mathrm{HCl}$ $(5 \times 400 \mathrm{ml})$ each time followed by centrifugation. The suspension of the polymer in water was finally lyophilized yielding $5.09 \mathrm{~g}(34.9 \mathrm{mmol}, 82 \%)$ of 15a,b, H-form. For ${ }^{1} \mathrm{H}-\mathrm{NMR}$ a sample was dissolved in $0.25 \mathrm{M}$ sodium phosphate, $\mathrm{pH} 7.5$, dialyzed against water, filtered $(0.45 \mu \mathrm{m})$, and pretreated with $\mathrm{D}_{2} \mathrm{O}$ as described above.
Conjugate of $S_{2}-P H E G$ and $N$-tert-butoxycarbonyl2,2'-oxybis(ethylamine) 4 ( $S_{2}-P H E G-O E A-B O C$

$16 a, b)$

To a stirred solution of $\mathbf{1 5 a} \mathbf{a}, \mathbf{b}, \mathrm{H}$-form ( $4.80 \mathrm{~g}, 32.9$ $\mathrm{mmol})$ in DMF (75 ml) saccharinic acid $(7.14 \mathrm{~g}, 39.0$ mmol) and $N, N^{\prime}$-carbonyldiimidazole (CDI) $(7.11 \mathrm{~g}$, $43.9 \mathrm{mmol}$ ) were successively added. After $30 \mathrm{~min}$ at room temperature 2-aminoethanol ( $29 \mathrm{ml}, 0.484 \mathrm{~mol}$ ) was added and the mixture was stirred for 4 days at room temperature. The mixture was dissolved in 0.25 $M$ sodium phosphate buffer, $\mathrm{pH} 7.5(600 \mathrm{ml})$, acidified to $\mathrm{pH} 6.0$ with $4 \mathrm{M} \mathrm{H}_{3} \mathrm{PO}_{4}$ and filtered $(0.45 \mu \mathrm{m})$. The solution was dialyzed against $0.2 \mathrm{M} \mathrm{NaCl}(3 \times 20 \mathrm{l})$ and water $(4 \times 201)$ at $4^{\circ} \mathrm{C}$ and was finally lyophilized.

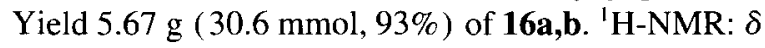
$=1.40\left(\mathrm{~s}, 9.1 \mathrm{~mol} \%\right.$ of $9 \mathrm{H}$ relative to $\left.\mathrm{Glu},-\left(\mathrm{CH}_{3}\right)_{3}\right)$; $2.07\left(\mathrm{~m}, 2 \mathrm{H}\right.$, Glu $\left.\beta-\mathrm{CH}_{2}\right) ; 2.38\left(\mathrm{~m}, 2 \mathrm{H}\right.$, Glu $\left.\gamma-\mathrm{CH}_{2}\right)$; $3.29(\mathrm{t})$ and $3.60(\mathrm{t})(95.8 \mathrm{~mol} \%$ of $4 \mathrm{H}$ relative to Glu, $-\mathrm{NDCH}_{2} \underline{\mathrm{CH}}_{2} \mathrm{OD} ; 9.1 \mathrm{~mol} \%$ of $8 \mathrm{H}, \quad-\underline{\mathrm{CH}}_{2} \underline{\mathrm{CH}}_{2}-$ $\left.\mathrm{OCH}_{2}{ }_{2} \underline{\mathrm{C}}_{2}^{-}\right) ; 4.25\left(\mathrm{~s}, 1 \mathrm{H}\right.$, Glu $\left.\alpha-\mathrm{CH}_{2}\right)$.

Conjugate of $S_{2}-P H E G$ and 2,2'-oxybis(ethylamine) $\left(\mathrm{S}_{2}-\mathrm{PHEG}-\mathrm{OEA}-\mathrm{NH}_{2}\right.$ I7a,b)

Conjugate 16a,b $(2.50 \mathrm{~g}, 13.5 \mathrm{mmol})$ was dissolved in TFA $(70 \mathrm{ml})$ with stirring at room temperature. After 8 min the solution was evaporated to dryness in vacuo within the next $5 \mathrm{~min}$ and the oily residue was dissolved in $0.25 \mathrm{M}$ sodium phosphate buffer, $\mathrm{pH} 8.0$ $(150 \mathrm{ml})$. The $\mathrm{pH}$ of the solution was adjusted to 6.0 with $4 \mathrm{M} \mathrm{NaOH}$. The solution was filtered $(0.45 \mu \mathrm{m})$, concentrated to $100 \mathrm{ml}$ by ultrafiltration, desalted by diafiltration against water $(700 \mathrm{ml})$ and finally lyophilized. Yield $1.94 \mathrm{~g}(10.5 \mathrm{mmol}, 78 \%)$ of 17a,b, phosphate salt. 'H-NMR $\left(\mathrm{D}_{2} \mathrm{O}\right): \delta=2.07(\mathrm{~m}, 2 \mathrm{H}$, Glu $\left.\beta-\mathrm{CH}_{2}\right) ; 2.38\left(\mathrm{~m}, 2 \mathrm{H}\right.$, Glu $\left.\gamma-\mathrm{CH}_{2}\right) ; 3.28(\mathrm{t})$ and 3.60 (t) $(89.3 \mathrm{~mol} \%$ of $4 \mathrm{H}$ relative to Glu, $\left.-\mathrm{NDCH}_{2} \underline{\mathrm{CH}}_{2} \mathrm{OD}\right) ; 3.18(\mathrm{t})$ and $3.71(\mathrm{t})(9.0 \mathrm{~mol} \%$ of $4 \mathrm{H}$, spacer- $\left.\mathrm{CH}_{2}\right) ; 4.26\left(\mathrm{~s}, 1 \mathrm{H}\right.$, Glu $\left.\alpha-\mathrm{CH}_{2}\right)$. Other spacer- $\mathrm{CH}_{2}$ signals are buried under the deuterium oxyethylamide signals.

Conjugate of PHEG and 1,4-diaminobutane (PHEGbutyl- $\mathrm{NH}_{2}$ (8)

The conjugate of PHEG and 1,4-diaminobutane (PHEG-butyl- $\mathrm{NH}_{2}$ 18) was prepared from highmolecular weight PGA 14b $\left(M_{\mathrm{w}} 73000\right)$ and 8 according to the procedure described above. 'H-NMR $\left(\mathrm{D}_{2} \mathrm{O}\right): \delta=2.09 \mathrm{~m}\left(2 \mathrm{H}\right.$, Glu $\left.\beta-\mathrm{CH}_{2}\right) ; 2.38 \mathrm{~m}(2 \mathrm{H}, \mathrm{Glu}$ 
$\left.\gamma-\mathrm{CH}_{2}\right) ; 3.30(\mathrm{t})$ and $3.61(\mathrm{t})(90 \mathrm{~mol} \%$ of $4 \mathrm{H}$ relative to Glu, $\left.-\mathrm{NDCH}_{2} \mathrm{CH}_{2} \mathrm{OD}\right) ; 1.59(\mathrm{~m}), 2.98(\mathrm{t})$ and 3.20 (m) $\left(10 \mathrm{~mol} \%\right.$ of $\left.\overline{4 H}, \underline{\mathrm{CH}}_{2} \mathrm{CH}_{2} \mathrm{CH}_{2} \underline{\mathrm{CH}}_{2}\right) ; 4.25 \mathrm{~s}(1 \mathrm{H}$, Glu $\alpha-\mathrm{CH}_{2}$ ).

\section{Fractionation of PHEG carriers by SEC}

Conjugate 17a,b was fractionated in batches of 110 mg by gel filtration on a TSK Fraktogel HW-55S column $(95 \times 2.6 \mathrm{~cm} ; 500 \mathrm{ml})$ equilibrated in buffer II as described previously [10] yielding a 'high molecular weight' (HMW) and a 'low molecular weight' (LMW) polymer fraction which were desalted by diafiltration against water and then lyophilized. The ${ }^{1} \mathrm{H}-$ NMR spectrum of the LMW fraction was identical with that of the parent polymer.

Conjugate of $\mathrm{S}_{2}$-PHEG-OEA-NH $\mathrm{H}_{2}$ 17a,b and thioacetyl- $\beta$-Ala-Asp-ADR $\left(S_{2}-P H E G-A D R\right.$ 19a,b)

To a solution of 17a,b LMW ( $120.0 \mathrm{mg}, 0.65 \mathrm{mmol}$ of carrier; $0.058 \mathrm{mmol}$ of $\left.\mathrm{NH}_{2}\right)$ in DMSO $(5.25 \mathrm{ml})$ a solution of TEA $(0.13 \mathrm{mmol})$ in DMSO $(0.266 \mathrm{ml})$ and GMBS ( $55.9 \mathrm{mg}, 0.20 \mathrm{mmol}$ ) were successively added. After stirring the solution for $60 \mathrm{~min}$. at room temperature, remaining amino groups were acylated by the addition of $N$-succinimidyl acetate (AcOSu) (31.3 $\mathrm{mg}, 0.20 \mathrm{mmol}$ ) and the solution was stirred for an additional $90 \mathrm{~min}$ at room temperature. The solution was mixed with buffer I $(27.0 \mathrm{ml})$ and the solution was filtered $(0.45 \mu \mathrm{m})$. The filtrate was applied to a Sephadex G-25 column. The polymer-containing fractions were pooled ( $48 \mathrm{ml}$ ) and the PHEG-bound maleimide concentration ( $1.039 \mathrm{mM}$ ) was determined by the Cys/DTP assay. The PHEG-maleimide conjugate ( $47.5 \mathrm{ml}$ ) was concentrated to $18.0 \mathrm{ml}$ by ultrafiltration and buffer $(2.0 \mathrm{ml})$ was added. To the solution of PHEG-bound maleimide in buffer I (12.4 ml) DMF $(6.2 \mathrm{ml}), 9(47.8 \mathrm{mg}, 0.056 \mathrm{mmol})$ and a solution of $\mathrm{NH}_{2} \mathrm{OH}(0.19 \mathrm{mmol})$ in buffer I $(0.38 \mathrm{ml})$ were subsequently added with stirring. The reaction mixture was stirred for $45 \mathrm{~min}$ at room temperature protected from light. The solution was applied to a column of Sephadex LH-20 $(56 \times 2.6 \mathrm{~cm})$ equilibrated in DMF/buffer I $(1 / 2 \mathrm{v} / \mathrm{v} ; \mathrm{pH} 7.5)$. Elution took place with the same solvent at a flow rate of $120 \mathrm{ml} / \mathrm{h}$. The fractions eluting at the void volume were pooled and the solution was applied to a column of Sephadex G-25 equilibrated in buffer I. Elution took place with the same solvent at a flow rate of $270 \mathrm{ml} / \mathrm{h}$. The fractions eluting at the void volume were pooled and the solution of 19a,b ( 300 $\mathrm{ml}$ ) was concentrated to $20.7 \mathrm{ml}$ by ultrafiltration. The solution was analyzed for the content of thiol groups after reduction using the Cys/DTP assay and for the content of Glu (carrier), $\gamma$-aminobutyric acid (maleimide linker) and $\beta$-Ala (ADR) by amino acid analysis after acidic hydrolysis.

To allow radiolabelling of the ADR conjugate, amino groups were introduced by a slight modification of the above procedure. The solution of PHEG-bound maleimide in buffer I was reacted with cysteamine ( 10 mol\% of maleimido groups) in buffer I for $10 \mathrm{~min}$ at room temperature. Subsequently, the coupling of the ADR derivative was performed as described.

Conjugate of PHEG and thioacetyl- $\beta$-Ala- $\beta$ methyl,dehydroAsp-ADR (PHEG-ADR 20)

To a solution of 18 ( $29.6 \mathrm{mg}, 0.16 \mathrm{mmol}$ of carrier; $0.016 \mathrm{mmol}$ of $\mathrm{NH}_{2}$ ) in $50 \mathrm{mM} \mathrm{Na} 2 \mathrm{HPO} 4 / \mathrm{H}_{3} \mathrm{PO} 4,1$ mM EDTA buffer, pH 8.5 ( $1.5 \mathrm{ml}$ ) sulfo-SMCC ( 21.3 $\mathrm{mg}, 0.048 \mathrm{mmol}$ ) was added and the mixture was stirred for $30 \mathrm{~min}$. at room temperature. The reaction mixture was mixed with buffer I $(28.5 \mathrm{ml})$ and the solution was filtered $(0.45 \mu \mathrm{m})$. The filtrate was applied to G-25 (PD-10) columns ( 14 columns; 2.0 $\mathrm{ml}$ sample volume each). The polymer-containing fractions were pooled $(45 \mathrm{ml})$ and the PHEG-bound maleimide concentration $(0.121 \mathrm{mM})$ was determined by Cys/DTNB assay. To the solution of PHEG-bound maleimide in buffer I (42 ml) $\mathbf{1 0}(9.0 \mathrm{mg}, 9.1 \mu \mathrm{mol})$ and a solution of $\mathrm{NH}_{2} \mathrm{OH}(0.45 \mathrm{mmol})$ in buffer I $(0.9$ $\mathrm{ml})$ were subsequently added with stirring. The reaction mixture was stirred for $45 \mathrm{~min}$. at room temperature protected from light. Part of the solution $(21 \mathrm{ml})$ was frozen and kept overnight in the freezer. A mixture of the solution $(21 \mathrm{ml})$ and DMF $(10 \mathrm{ml})$ was applied to a column of Sephadex LH-20 $(31 \times 2.6 \mathrm{~cm})$ equilibrated in DMF/buffer I ( $1 / 2 \mathrm{v} / \mathrm{v} ; \mathrm{pH} 7.5)$. Elution took place with the same solvent at a flow rate of 70 $\mathrm{ml} / \mathrm{h}$ and the fractions eluting at the void volume were pooled. The other part of the reaction mixture was treated similarly. Both polymer solutions obtained after LH-20 purification were pooled and the solution was applied to a column of Sephadex G-25 equilibrated in buffer I. Elution took place with the same solvent at a flow rate of $270 \mathrm{ml} / \mathrm{h}$. The fractions eluting at the void volume were pooled and the solution of $20(150 \mathrm{ml})$ 
was concentrated to $25 \mathrm{ml}$ by ultrafiltration. The solution was stored at $4^{\circ} \mathrm{C}$.

Immunoconjugate of $\operatorname{IgM} 16.88$ and $S_{2}-P H E G-A D R$ 19a,b (IgM-PHEG-ADR 22)

To a solution of IgM $16.88(13.75 \mathrm{mg})$ in buffer I $(2.5 \mathrm{ml})$ was added a solution of GMBS $(0.6 \mu \mathrm{mol}$; $40 \mathrm{~mol}$ of GMBS/mol of IgM) in DMF $(0.060 \mathrm{ml})$. The reaction mixture was kept at room temperature for $1 \mathrm{~h}$ and excess reagent and low-molecular weight reaction products were removed by gel filtration on Sephadex G-25 (PD-10) columns equilibrated in buffer III. The eluate containing maleimido-activated IgM 16.88 (GMB-IgM 21) was stored at $4^{\circ} \mathrm{C}$ and used within $1 \mathrm{~h}$. The concentration of IgM-bound maleimido groups as determined by the Cys/DTNB depletion assay was $7.37 \times 10^{-5} \mathrm{M}$ (degree of substitution 18 $\mathrm{mol}$ of maleimido groups $/ \mathrm{mol}$ of $\mathrm{IgM}$ ). To a solution of 19a,b (batch $3,7.9 \mathrm{mg}$ ) in buffer I $(2.2 \mathrm{ml})$ were added buffer I $(2.2 \mathrm{ml})$ and a solution of Cys $(25$ $\mu \mathrm{mol})$ in buffer $\mathrm{I}(0.1 \mathrm{ml})$. The mixture was incubated for $20 \mathrm{~min}$ at $37^{\circ} \mathrm{C}$. Subsequently, a solution of DTT $(0.25 \mathrm{mmol})$ in buffer I $(0.5 \mathrm{ml})$ was added and the mixture was incubated for $1 \mathrm{~h}$ at $37^{\circ} \mathrm{C}$. Excess reagent and low-molecular weight reaction products were removed by repeated gel filtration on Sephadex G-25 (PD-10) columns equilibrated in buffer III. The eluate containing reduced 19a,b was stored at $4^{\circ} \mathrm{C}$ and used within $1 \mathrm{~h}$. The concentration of free polymer-bound thiol groups as determined by the DTNB assay was $3.8 \times 10^{-5} \mathrm{M}$. Solutions of 21 ( $2.0 \mathrm{ml} ; 0.147 \mu \mathrm{mol}$ of maleimido groups) and reduced $19 \mathbf{a}, \mathbf{b}(3.8 \mathrm{ml} ; 0.144$ $\mu \mathrm{mol}$ of thiol groups) were mixed with stirring and the reaction was allowed to proceed for $15 \mathrm{~h}$ at $4^{\circ} \mathrm{C}$. A solution of cysteamine $(0.22 \mu \mathrm{mol} ; 1.5 \mathrm{~mol}$ of cysteamine/mol of maleimido groups) in buffer III ( 0.022 $\mathrm{ml}$ ) was added and the mixture was incubated for 30 min at room temperature. Subsequently, the reaction mixture was applied on a column of TSK Fraktogel HW-55S ( $80 \times 2.6 \mathrm{~cm} ; 425 \mathrm{ml})$ equilibrated in buffer IV. Elution was performed with buffer IV as the eluent at a flow rate of $35-40 \mathrm{ml} / \mathrm{h}$ and fractions of $5.4 \mathrm{ml}$ were collected. The UV absorbance of the eluate was monitored at 280 and $490 \mathrm{~nm}$. Fractions 23 and 24 containing the immunoconjugate IgM-PHEG-ADR 22 were pooled and the solution was diluted with an equal volume of $25 \mathrm{mM}$ Tris $\cdot \mathrm{HCl}$ buffer, $\mathrm{pH}$ 8.0. The solution was applied on a column of Q-Sepharose Fast Flow
$(12 \times 1.6 \mathrm{~cm} ; 24 \mathrm{ml})$ equilibrated in buffer V. Ster elution was performed with $25 \mathrm{mM}$ Tris $\mathrm{HCl}$ bu $\mathrm{pH} 8.0$, containing sequentially $70,100,150,200$, 300 and $400 \mathrm{mM} \mathrm{NaCl}$ at a flow rate of $25-30 \mathrm{r}$ The UV absorbance of the eluate was monitored a and $490 \mathrm{~nm}$. Unreacted 19a,b was eluted with br containing 70-150 $\mathrm{mM} \mathrm{NaCl}$ and 22 was desorbr buffers containing 200-250 $\mathrm{mM} \mathrm{NaCl}$. The unre: IgM was mainly eluted by buffers containing 250 $\mathrm{mM} \mathrm{NaCl}$. Immunoconjugate fractions were col trated by ultrafiltration and sterilized by filtr through a $0.20 \mu \mathrm{m}$ filter. HP-SEC analysis was formed on a Zorbax GF-450 $(300 \times 7.8 \mathrm{~mm})$ co using $0.20 \mathrm{M}$ sodium phosphate buffer, $\mathrm{pH} 7.0$ a eluent at a flow rate of $1.0 \mathrm{ml} / \mathrm{min}$. The absorban the column eluate was simultaneously monitored a and $500 \mathrm{~nm}$.

Radiolabelling of IgM 16.88 and $S_{2}-P H E G-A D R 1$

Radio-iodination of IgM 16.88 with ${ }^{131}$ I was ca out prior to preparation of immunoconjugate follo the iodogen labelling procedure [10]. Protein (30 was incubated with $\mathrm{Na}{ }^{131} \mathrm{I}(50 \mu \mathrm{Ci} / \mathrm{mg}$ proteir vials coated with $100 \mu \mathrm{g}$ iodogen in PBS, pH 6.8 $5 \mathrm{~min}$ at $0^{\circ} \mathrm{C}$. Labelling of IgM 16.88 with ${ }^{3} \mathrm{H}$ accomplished by reaction of the protein with $\mathrm{N}$-s nimidyl $\left[2,3-{ }^{3} \mathrm{H}\right]$ propionate $(50 \mu \mathrm{Ci} / \mathrm{mg}$ protei $\mathrm{DMF} / \mathrm{PBS} 1 / 4 \mathrm{v} / \mathrm{v}, \mathrm{pH} 8.0$, for $2 \mathrm{~h}$ at 1 temperature. Conjugate 19a,b containing cystean derived amino groups (see above) was labelle reaction with $\mathrm{N}$-succinimidyl-3-(4-hydros $\left[{ }^{125} \mathrm{I}\right]$ iodophenyl)propionate (Bolton-Hunter gent) ( $50 \mu \mathrm{Ci} / \mathrm{mg}$ conjugate) in phosphate buffe, 8.0. Excess non-bound reagents were removed $b$ : filtration on prepacked Sephadex G-25 colv (PD10, Pharmacia, Sweden) equilibrated in PBS

Determination of immunoreactivity by enzyme-li immunoassay (EIA)

Method A: active immunoreactivity

Colon tumour-associated antigen CTA-1 obtained by Nonidet extraction of HT-29 cells follc by ammonium sulfate precipitation at $20 \%$ satur: [8]. Microtiter plates were coated ( $110 \mu \mathrm{l} /$ well) a solution of CTA-1 in PBS $(5 \mu \mathrm{g} / \mathrm{ml})$ for 15 at The wells were blocked by treatment with Blotto I $\mu \mathrm{l} /$ well) for $15 \mathrm{~h}$ at $4^{\circ} \mathrm{C}$ followed by washing PBS/Tween. Solutions of IgM or 22 were ser 
diluted across the plate ( $100 \mu \mathrm{l} /$ well $)$ and incubated for $1 \mathrm{~h}$ at $20^{\circ} \mathrm{C}$. After 3-fold washing with PBS/Tween the plate was incubated with horseradish peroxidase(HRP)-linked goat anti-human IgM in PBS (1 $\mathrm{mg} / \mathrm{ml}$ diluted $1: 16000$ ) for $1 \mathrm{~h}$ at $20^{\circ} \mathrm{C}$. After washing with PBS/Tween (three times) and water the plates were incubated with a solution ( $100 \mu \mathrm{l} /$ well) containing 3,3',5,5'-tetramethylbenzidine (TMB) $(0.3 \mathrm{mM})$ and urea hydrogen peroxide $(1.3 \mathrm{mM})$. The reaction was stopped with $4 \mathrm{~N} \mathrm{H}_{2} \mathrm{SO}_{4}(25 \mu \mathrm{l} /$ well $)$ and the absorbance at $450 \mathrm{~nm}$ was measured using a plate reader. The titre is defined as the reciprocal concentration of IgM or immunoconjugate giving half of the maximum absorbance and is expressed as \% relative to IgM.

\section{Method B: passive immunoreactivity}

Microtiter plates were coated $(110 \mu \mathrm{l} /$ well $)$ with serially diluted solutions of IgM or 22 for $1 \mathrm{~h}$ at $20^{\circ} \mathrm{C}$. The wells were blocked by treatment with Blotto ( 250 $\mu \mathrm{l} /$ well) for $15 \mathrm{~h}$ at $4^{\circ} \mathrm{C}$ followed by threefold washing with PBS/Tween. The plate was then incubated with HRP-linked goat anti-human IgM and end-point determination was carried out as described above.

\section{In vitro release of $A D R$ from $P H E G-A D R$ conjugates}

To study the release of ADR and ADR-related extractable products, PHEG-ADR conjugates 20 were incubated at a final anthracycline concentration of 10 $\mathrm{mM}$ in $50 \mathrm{mM}$ sodium phosphate buffer, $\mathrm{pH} 6.0$ or 7.5 at $37^{\circ} \mathrm{C}$. After various incubation times a sample $(0.20$ $\mathrm{ml}$ ) was mixed with $0.4 \mathrm{M}$ borate, $0.4 \mathrm{M} \mathrm{KCl}$ buffer, pH $9.0(1.0 \mathrm{ml})$ and a solution of daunomycin (internal standard) using a vortex mixer for $15 \mathrm{sec} . \mathrm{CHCl}_{3}$ / $\mathrm{CH}_{3} \mathrm{OH}(4 / 1 \mathrm{v} / \mathrm{v} ; 2.0 \mathrm{ml})$ was added and the suspension was mixed using a vortex mixer for $30 \mathrm{~s}$. After centrifugation the aqueous layer was discarded and the organic layer was evaporated under a stream of nitrogen. The residue was dissolved in $\mathrm{CH}_{3} \mathrm{OH}(0.15 \mathrm{ml})$ and the solution $(0.020 \mathrm{ml})$ was analyzed by HPLC using a RP- $\mu$ Bondapak $\mathrm{C}_{18}$ column $(300 \times 3.9 \mathrm{~mm} ; 10$ $\mu \mathrm{m}$ particle size) (Waters). The eluent was prepared by mixing solvent $\mathrm{A}\left(\mathrm{CH}_{3} \mathrm{OH} / 0.3 \mathrm{w} / \mathrm{v} \% \mathrm{NH}_{4} \mathrm{OAc}\right.$ in water $3 / 2 ; \mathrm{v} / \mathrm{v})$ and solvent $\mathrm{B}\left(\mathrm{CH}_{3} \mathrm{OH}\right)$ in a $85 / 15$ $(\mathrm{v} / \mathrm{v})$ ratio. The flow rate was $1.0 \mathrm{ml} / \mathrm{min}$. The absorbance of the eluate was monitored at $254 \mathrm{~nm}$. The amounts of ADR were determined from the peak areas using a calibration curve.

\section{Cytotoxicity experiments}

HT-29 human colon adenocarcinoma cells were grown in M 505 culture medium supplemented with $10 \%$ heat-inactivated fetal calf serum (FCS) at $37^{\circ} \mathrm{C}$ in an atmosphere containing $5 \% \mathrm{CO}_{2}$ maintained at $\mathrm{pH}$ 6.0 or 7.5 . Cell cultures were passaged twice weekly after detachment from the culture flasks using trypsin/ EDTA. Inhibition of cell growth was measured as follows. Suspensions of the cells in culture medium supplemented with FCS $\left(0.100 \mathrm{ml} ; 2 \times 10^{4}\right.$ cells $\left./ \mathrm{ml}\right)$ were pipetted into the wells of microtiter plates and incubated for $4 \mathrm{~h}$ to allow attachment of the cells to the surface. Stock solutions of ADR or $\mathbf{2 0}$ in PBS (up to 1 $\mathrm{mg}$ ADR-equivalents $/ \mathrm{ml}$ ) were serially diluted with culture medium supplemented with FCS and the solutions thus obtained $(0.100 \mathrm{ml})$ were added to the cells. The cells were grown in the presence of PHEG-ADR or ADR at $\mathrm{pH} 6.0$ and 7.5 for 1,3 or 5 days at $37^{\circ} \mathrm{C}$. The cells were then washed and incubated in fresh medium at $\mathrm{pH} 7.5$ until day 7 . After this period viable cells were determined with the 3-(4,5-dimethylthiazol2-yl)-2,5-diphenyl tetrazolium bromide (MTT)/formazan procedure [21]. A solution of MTT in culture medium $(0.050 \mathrm{ml} ; 1 \mathrm{mg} / \mathrm{ml})$ was added to each well and the cells were incubated for $4 \mathrm{~h}$ at $37^{\circ} \mathrm{C}$. The culture medium was removed, DMSO $(0.100 \mathrm{ml})$ was added to solubilize the MTT/formazan products generated by viable cells and the absorbance at $540 \mathrm{~nm}$ was measured. This value is taken as a relative measure of the concentration of viable cells. The inhibition of cell growth by $\mathbf{2 0}$ is expressed as the ratio of the $\mathrm{ID}_{50}$ value and the $\mathrm{ID}_{50}$ value of ADR.

Biodistribution and tumour uptake of ${ }^{3} \mathrm{H}$-labelled IgM 16.88, ${ }^{125}$ I-labelled $S_{2}$-PHEG-ADR 19a,b and ${ }^{13 l} I-$ labelled IgM-PHEG-ADR 22 in athymic nude mice

The human ovarian tumour line MRI-H-207 is an undifferentiated adenocarcinoma originally derived from a patient with generalized peritoneal metastases and considerable malignant involvement of both ovaries [22]. Xenografts of MRI-H-207 were established by subcutaneous injection of $5 \times 10^{6}$ cells into the left and right flank of athymic nude HSD mice ( 9 mice/ compound). The tumours were grown for 3 weeks, at which time the weight was usually between 100 and $500 \mathrm{mg} .150 \mu \mathrm{l}$ of a solution containing either equal amounts $(150 \mu \mathrm{g} ; 1 \mu \mathrm{Ci})$ of ${ }^{131}$ I-labelled 22 and ${ }^{3} \mathrm{H}$ labelled IgM or $150 \mu \mathrm{g}(1.5 \mu \mathrm{Ci})$ of ${ }^{125}$ I-labelled 19a,b 


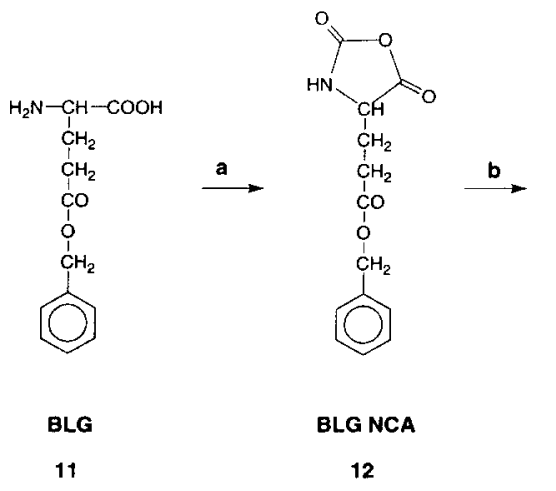

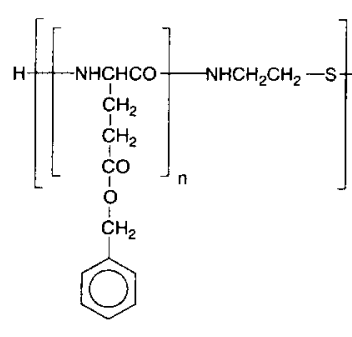

bis-PBLG-cystamide

13a

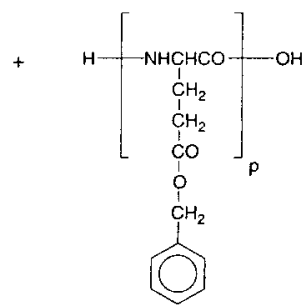

PBLG

13b

$13 a, b \quad S_{2}-P B L G$

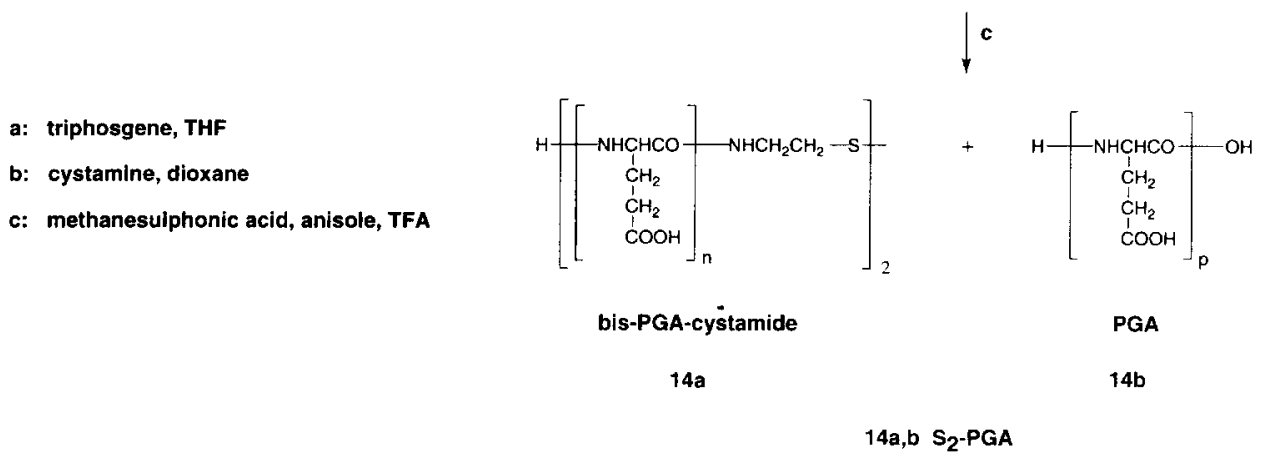

Fig. 1. Preparation of $S_{2}$-PGA 14a,b by polymerization of BLG NCA 12 using cystamine as the initiator followed by cleavage of benzyl ester groups.

in PBS was injected i.v into the tail vein of mice followed by injection of $50 \mu$ l of PBS in order to minimize the loss of labelled compound by bleeding. At 6, 24 and $48 \mathrm{~h}$ after administration, groups of three mice per compound were killed. The following tissues were collected: tumours; liver with gall-bladder; kidneys, without fat and adrenals; spleen; heart; lungs, muscle (tibialis) and thyroid with surrounding cartilage. Blood was collected by vena cava (abdominal) puncture under ether anaesthesia and K-EDTA was added. Urine was collected by bladder puncture and faeces were collected from the intestine. Blood, urine and tissues were weighed, and radioactivity was determined with a well-type $\gamma$-counter (Packard 5530). Data from tumours below $100 \mathrm{mg}$ were not used. After storage of the samples for 2 months at $-20^{\circ} \mathrm{C}$ the ${ }^{3} \mathrm{H}$ activity was measured by liquid scintillation after combustion of the samples. The activity is expressed as \% of the dose administered per $g$ of tissue, blood or urine ( $\%$ dose/ g).

\section{Results}

\subsection{Preparation of functionalized PHEG carrier}

PGA containing a terminal disulfide group ( $\mathrm{S}_{2}$-PGA $14 a, b)$ is used as the starting material for the selective coupling of polymer-bound ADR with antibodies. Polymer 14a,b was prepared by the method of Kato et al. [3] as described previously [10] in which the thiol group is introduced at the C-terminal polymer end (Fig. 1; Table 1). BLG 11 was converted to the $\mathrm{N}$ carboxyanhydride (BLG NCA 12) which was polymerized in dioxane using cystamine as the initiator. The polymer obtained is a mixture of bis-PBLG-cystamide 13a and PBLG 13b [3]. The benzyl side chains of the polymer mixture were cleaved with methanesulphonic acid/TFA in the presence of anisole to scavenge benzyl cations yielding 14a,b. Separation of the polymer into cystamide-terminated PGA (bis-PGA-cystamide 14a) and PGA 14b [10] was omitted because 


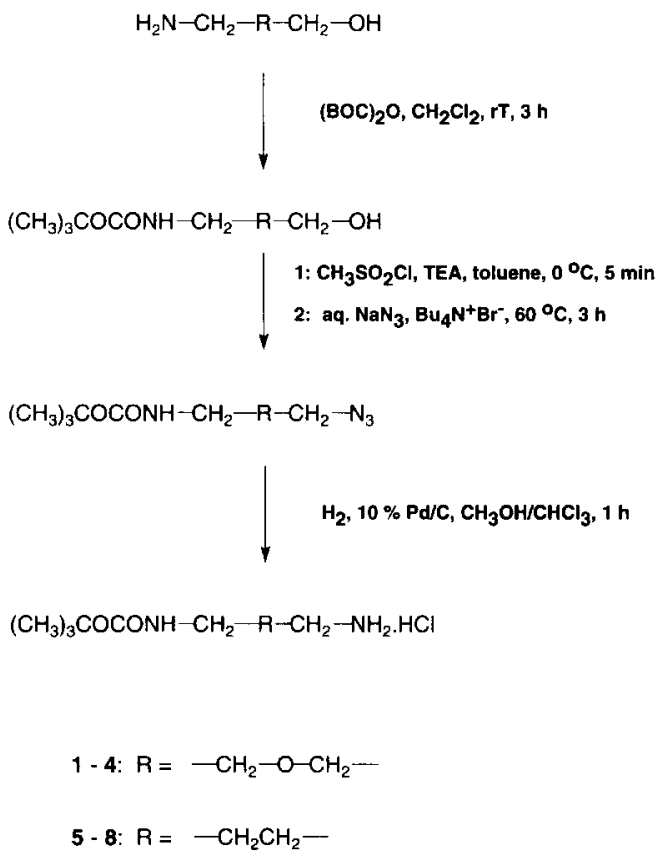

Fig. 2. Preparation of monosubstituted diamine spacers $\mathrm{BOC}-\mathrm{OEA}$ 4 and BOC-AB 8

purification of the PHEG-containing immunoconjugate could be accomplished by ion-exchange chromatography as discussed below.

The introduction of maleimido or amino groups onto PHEG to allow the subsequent coupling of drug derivatives was attempted by activation of the hydroxyl groups of the polymer. PHEG was activated by $p$ tosylchloride $[23,24]$ tresylchloride [24] and $p$-nitro-

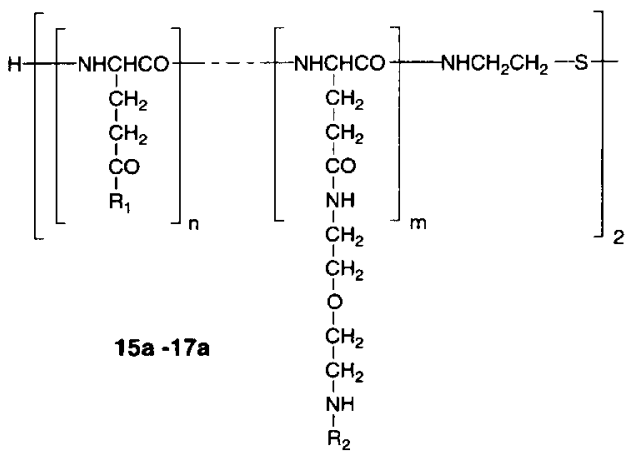

phenylchloroformate $[25,26]$ and the activated polymer was reacted with $\mathrm{N}$-maleimido-1,4-diaminobutane or BOC-AB 8. These experiments resulted in partial formation of insoluble (crosslinked) polymers, low degrees of spacer substitution and the presence of polymer-bound activating groups remaining after the coupling reaction. The maleimido group of $N$-maleimido-1,4-diaminobutane proved to be unstable when the free base was generated from the hydrochloride in organic solvents with TEA, probably due to nucleophilic Michael-type addition on the double bond.

The results prompted us to develop an alternative route to prepare PHEG carriers having functional amino groups for attachment of ADR derivatives described below in addition to polymer-bound disulfide groups for the coupling to antibody starting from $14 a, b$ (Fig. 2 and 3). In order to prevent crosslinking of polymer chains upon introduction of diamine-containing spacers, the monosubstituted BOC-derivatives of 2,2'oxybis (ethylamine) 4 and 1,4-diaminobutane 8 were prepared using the procedure described by Mattingly [19] (Fig. 2). Polymer 14a,b was reacted with 10 mol\% of BOC-OEA 4 using EEDQ as the coupling agent in DMF as described previously for the coupling of adriamycin to PGA [27] to give $\mathrm{S}_{2}$-PGA-OEABOC conjugate 15a,b as the sodium salt with a degree of substitution of $9.1 \mathrm{~mol} \%$ of spacer (Fig. 3). The conjugate was converted to the acid form by precipitation in $0.1 \mathrm{M} \mathrm{HCl}$. The BOC group proved to be stable under these acid conditions as shown by ${ }^{1} \mathrm{H}$ -

$$
\begin{array}{ll}
\text { 15a,b } S_{2} \text {-PGA-OEA-BOC } & \mathrm{R}_{1}=\mathrm{OH}, \mathrm{R}_{2}=\mathrm{COOC}\left(\mathrm{CH}_{3}\right)_{3} \\
\text { 16a,b } S_{2} \text {-PHEG-OEA-BOC } & \mathrm{R}_{1}=\mathrm{NHCH}_{2} \mathrm{CH}_{2} \mathrm{OH}, \mathrm{R}_{2}=\mathrm{COOC}\left(\mathrm{CH}_{3}\right)_{3} \\
\text { 17a,b } \mathrm{S}_{2} \text {-PHEG-OEA-NH } & \mathrm{R}_{1}=\mathrm{NHCH}_{2} \mathrm{CH}_{2} \mathrm{OH}, \mathrm{R}_{2}=\mathrm{H}
\end{array}
$$

Fig. 3. Structure of conjugates of disulfide-terminated polymeric carriers and 2,2'-oxybis(ethylamine) prepared from $\mathrm{S}_{2}-\mathrm{PGA} \mathbf{1 4 a , b}$. 
NMR. The remaining carboxyl groups of the PGAspacer graft were fully converted to 2-hydroxyethylamide groups as described previously for the preparation of PGA-peptide conjugates [27] yielding the $\mathrm{S}_{2}$-PHEG-OEA-BOC conjugate $\mathbf{1 6 a}, \mathbf{b}$. The conversion of acid groups to 2-hydroxyethylamide groups was confirmed by 'H-NMR. Subsequently, the BOC group was removed to give the $S_{2}$-PHEG-OEA$\mathrm{NH}_{2}$ conjugate $17 \mathbf{a}, \mathbf{b}$ in an overall yield of $59 \%$ relative to $14 a, b$. Elution of $17 \mathbf{a}, \mathbf{b}$ on a high porosity gel filtration column (TSK Fraktogel HW-55S) shows a broad molecular weight range as discussed previously [10]. Prior to further coupling steps the carrier was fractionated by gel filtration and only the low molecular weight fraction designated LMW [10] was used in the preparation of ADR conjugates.

The degree of substitution of $14 a, b$ with 4 could be varied by adjusting the molar ratio of polymer and spacer. When using $5 \mathrm{~mol} \%$ of spacer, $17 \mathbf{a}, \mathbf{b}$ conjugates with 4.1-4.5 mol\% degree of substitution were obtained. Similarly, use of 20 and $30 \mathrm{~mol} \%$ spacer yielded conjugates with a degree of substitution of 18 and $26 \mathrm{~mol} \%$, respectively.

The use of 2-pyridyldithio-protected PGA (PDTPGA) instead of 14a,b was initially attempted in the above procedure. PDT-PGA was obtained by reduction of $\mathbf{1 4 a , b}$ followed by covalent chromatography using thiopropyl-Sepharose and protection of thiol-PGA as the PDT derivative as described previously [10]. A significant loss of PDT groups was observed after the coupling step with 2-aminoethanol indicating decomposition by the strongly basic amine, although polymerbound thiol groups could still be generated by reduction with DTT. These results prompted us to change to the use of $14 \mathbf{a}, \mathbf{b}$ due to the enhanced stability of the disulfide moiety in the presence of 2-aminoethanol.

A conjugate of PHEG and 1,4-diaminobutane designated as PHEG-butyl- $\mathrm{NH}_{2} \mathbf{1 8}$ was obtained from high-molecular weight $\left(M_{\mathrm{w}} 73000\right)$ PGA without thiol end groups 14b [14,27] and 8 using the method described above. The degree of spacer substitution was $10 \mathrm{~mol} \%$ as determined by ${ }^{1} \mathrm{H}-\mathrm{NMR}$.

\subsection{Molecular weights of polymeric carriers}

Analysis of the molecular weight distribution of three batches of $S_{2}$-PBLG 13a,b by HP-SEC/LALLS shows a major fraction of medium-sized average molecular weight $\left(M_{\mathrm{w}}, M_{\mathrm{n}}\right)$ or average degree of polymerization $\left(\mathrm{DP}_{\mathrm{w}}, \mathrm{DP}_{\mathrm{n}}\right.$ ) (Table 1). The polymer batches contain a minor fraction of high-molecular weight which may be due to aggregation [28] and the HP-SEC/LALLS data of this fraction were not used in the calculation of molecular weight averages. Comparison of the weight-average degrees of polymerization $\left(D_{w}\right)$ of different batches of $S_{2}$-PGA 14a,b as determined by viscometry with the values of the parent PBLG batches indicates that some chain scission, in the order of $0.07-0.19 \%$ of amide bonds, had occurred as a result of the acid deprotection step. $\mathrm{S}_{2}$-PHEGOEA-BOC 16a,b and various batches of $S_{2}$-PHEGOEA- $\mathrm{NH}_{2}$ 17a,b showed a unimodal distribution in HP-SEC/LALLS. The average molecular weights and average degrees of polymerization obtained for $16 \mathbf{a}, \mathbf{b}$ or $\mathbf{1 7 a}, \mathbf{b}$ (crude) are significantly higher than those of the precursor polymer 14a,b. However, the values of the PHEG-spacer conjugates are only apparent because the sequence and composition dependence of the refractive index increment $(\mathrm{d} n / \mathrm{d} c)$ [29] due to the random nature of the copolymers is difficult to estimate and is not accounted for in the data processing. An improved estimate of the absolute molecular weight of the copolymers might be obtained by measuring the apparent molecular weight in different solvents and correcting for the dependence on $\mathrm{d} n / \mathrm{d} c$ of the solvent [29]. The separation of crude $\mathbf{1 7} \mathbf{a}, \mathbf{b}$ into a high- and low-molecular weight fraction is confirmed by the values of the apparent average molecular weights of the HMW and LMW fractions.

\subsection{Preparation of $A D R$ derivatives}

New derivatives of ADR in which the drug is bound either through an acid-labile maleamic acid bond or a hydrolytically stable amide bond and which also contain a thiol functional group, present as the $S$-acetylthioacetic acid (SATA) moiety, for coupling with carriers have been prepared $[11,12,20]$. The acid-labile compound SATA- $\beta$-Ala- $\beta$-methyl,dehydroAsp-ADR 10 (Fig. 5) and the hydrolytically stable compound SATA- $\beta$-Ala-Asp-ADR 9 (Fig. 4) which is used in immunoconjugates as a control will be described in detail elsewhere [20]. For coupling to maleimide-activated carriers the ADR derivatives are converted to the corresponding free thiol by cleavage of the acetyl moiety in situ with hydroxylamine. 


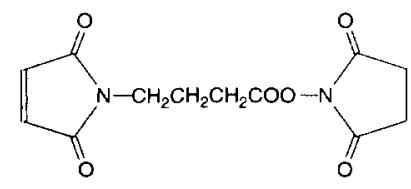

GMBS

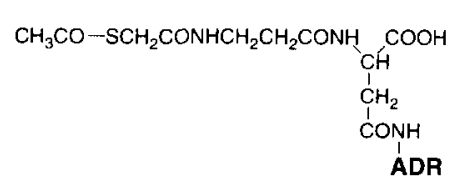

SATA- $\beta$-Ala-Asp-ADR

9

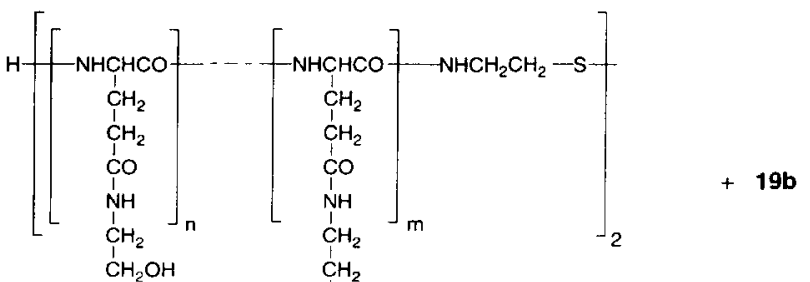

$19 a$

$\mathrm{CH}_{2}$

$\mathrm{P}_{2}$

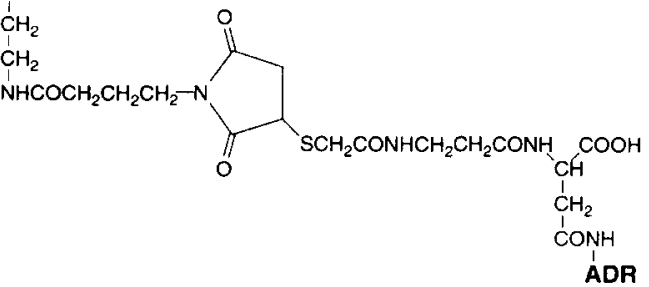

$S_{2}$-PHEG-ADR

$19 a, b$

ÁDR

Fig. 4. Structure of $S_{2}$-PHEG-ADR 19a,b prepared from $S_{2}$-PHEG-OEA-NH $\mathrm{H}_{2}$ 17a,b, GMBS and SATA- $\beta$-Ala-Asp-ADR 9.

\subsection{Preparation of PHEG-ADR conjugates}

Maleimido groups were introduced onto PHEG conjugates with amine-containing spacers by acylation with GMBS $[30,31]$ or the water-soluble sulfo derivative of SMCC [32]. The polymer-bound maleimido groups were reacted with the thiol-containing ADR derivatives to allow for the formation of conjugates through a thioether bond (Fig. 4 and 5).

The degree of substitution of PHEG with maleimido groups and ADR was determined by amino acid analysis of $\gamma$-aminobutyric acid (maleimido groups) and $\beta$-Ala (ADR) after hydrolysis of the conjugate $\mathrm{S}_{2}$-PHEG-ADR 19a,b in acid (Table 2). The maleim-

Table 2

Analytical data of PHEG-bound ADR conjugates prepared from $S_{2}$-PGA carrier 14a,b, BOC-OAE spacer 4, GMBS linker and SATA- $\beta$-AlaAsp-ADR 9

\begin{tabular}{|c|c|c|c|c|c|c|}
\hline Conjugate & OAE spacer $(\operatorname{mol} \%)$ & $\begin{array}{l}\text { Maleimido linker } \\
(\mathrm{mol} \%)\end{array}$ & $\operatorname{ADR}^{c}(\operatorname{mol} \%)$ & $\epsilon_{490}^{c}\left(\mathrm{M}^{-1} \mathrm{~cm}^{-1}\right)$ & $D P_{\text {n.app }}^{d}$ & $M_{\mathrm{n}, \mathrm{upp}}^{\mathrm{d}}\left(\times 10^{-4}\right)$ \\
\hline $\begin{array}{l}\text { 19a,b } S_{2} \text {-PHEG-ADR } \\
\text { batch } 1\end{array}$ & 9.1 & $7.20( \pm 0.02)$ & $5.70( \pm 0.18)$ & $6700( \pm 440)$ & $133( \pm 5)$ & $3.11( \pm 0.12)$ \\
\hline $\begin{array}{l}\text { 19a,b } S_{2} \text {-PHEG-ADR } \\
\text { batch } 2\end{array}$ & 9.1 & $7.49( \pm 0.22)$ & $5.75( \pm 0.12)$ & $5700( \pm 160)$ & $110( \pm 1)$ & $2.58( \pm 0.02)$ \\
\hline $\begin{array}{l}\text { 19a,b } S_{2} \text {-PHEG-ADR } \\
\text { batch } 3^{c}\end{array}$ & 9.1 & $7.43( \pm 0.004)$ & $5.83( \pm 0.01)$ & $6300( \pm 100)$ & $80( \pm 1)$ & $1.88( \pm 0.02)$ \\
\hline
\end{tabular}

aRelative to Glu as determined by ${ }^{1} \mathrm{H}-\mathrm{NMR}$.

'Calculated from the amounts of GABA and Glu as determined by amino acid analysis.

"Calculated from the amounts of $\beta$-Ala and Glu as determined by amino acid analysis.

${ }^{\mathrm{d}}$ Apparent value of reduced conjugate ( of thiol groups as determined by DTP assay.

${ }^{\mathrm{e}} \mathrm{Used}$ for the preparation of radiolabelled immunoconjugate. 


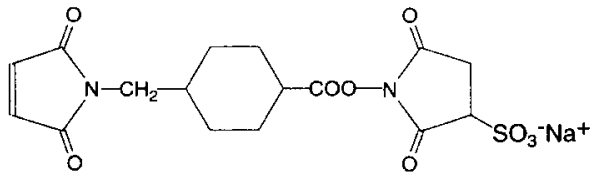

Sulfo-SMCC

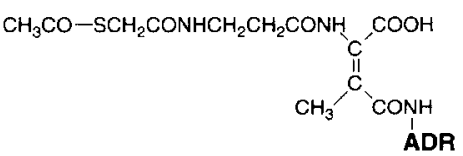

SATA- $\beta$-Ala- $\beta$-methyl,dehydroAsp-ADR

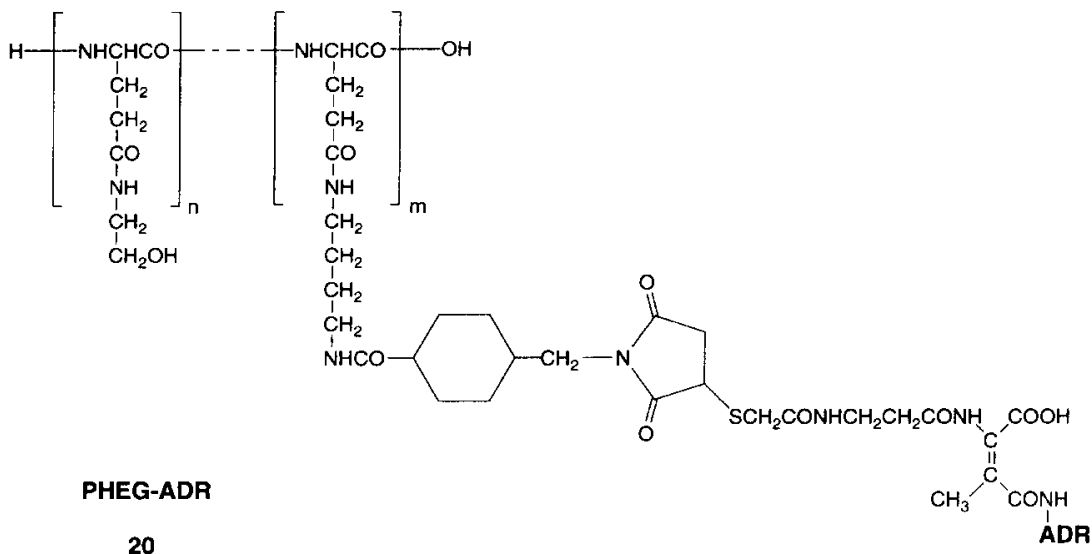

Fig. 5. Structure of PHEG-ADR 20 prepared from PHEG-butyl-NH $\mathrm{NH}_{2}$, sulfo-SMCC and SATA- $\beta$-Ala- $\beta$-methyl, dehydroAsp-ADR 10.

ido and ADR content of various preparations of conjugate indicate almost complete conversion in both coupling steps with the polymeric carrier. The molar absorbance coefficient of PHEG-bound ADR at 490 $\mathrm{nm}\left(\epsilon_{490}\right)$ is significantly reduced as compared to the value of free ADR ( $\left.9800 \mathrm{M}^{-1} \mathrm{~cm}^{-1}\right)$ which may be explained by intramolecular or intermolecular interaction of polymer-bound ADR residues [33]. Because 19a,b contains fractions with and without disulfide end groups, in unknown relative amounts, the actual values of the number-average degree of polymerization $\left(\mathrm{DP}_{\mathrm{n}}\right)$ of the thiol-terminated fraction of reduced conjugate will be less than the apparent values of $\mathrm{DP}_{\mathrm{n}}$ calculated from the content of thiol groups and the concentration of Glu as determined by amino acid analysis (Table 2). Due to the unknown polymer composition with respect to disulfide/thiol end groups these apparent $\mathrm{DP}_{\mathrm{n}}$ values cannot be directly compared with the molecular weight data of the polymer precursors discussed above.

The concentrations of PHEG-bound maleimido as well as ADR groups in soluble conjugates PHEG-ADR 20 (Fig. 5) were consistently lower by $50 \%$ or more in comparison with those obtained for conjugates 19a,b. Although the origin of these results was not investigated the data suggest partial formation of insol- uble conjugates mediated by the hydrophobicity of the ( $N$-maleimidomethyl) cyclohexane moiety.

\subsection{Preparation of radiolabelled immunoconjugates of $\mathrm{IgM} 16.88$ and $S_{2}-P H E G-A D R 19 a, b$}

The preparation of the immunoconjugate of $\operatorname{IgM}$ 16.88 and $S_{2}$-PHEG-ADR 19a,h is similar to that described previously [10]. The structure of the immunoconjugate is given in Fig. 6. Prior to immunoconjugation IgM 16.88 was labelled with ${ }^{131} \mathrm{I}$ using the iodogen procedure. ${ }^{131} \mathrm{I}$-labelled IgM 16.88 was reacted with GMBS to yield a degree of substitution of $18 \mathrm{~mol}$ of $\gamma$-maleimidobutyryl (GMB) groups per mol of antibody. The immunoreactivity at this degree of substitution is fully preserved but is gradually lost by increasing the GMB substitution above $20 \mathrm{~mol} / \mathrm{mol}$ (Fig. 7). Conjugate 19a,b was reacted with Cys to deactivate remaining polymer-bound maleimido groups and subsequently with DTT to reduce the disulfide end groups. Maleimido-activated $\operatorname{IgM}$ was then added to the thiol-containing conjugate 19a,b allowing for the formation of a thioether linkage between polymer and protein. By using equimolar amounts of protein-bound maleimido groups and polymer-bound thiol groups virtually complete reaction of both components 
<smiles>CN(CCN1C(=O)C2CCCC(C2)C1=O)C(C)(C)C</smiles>

Maleimido-activated IgM

21

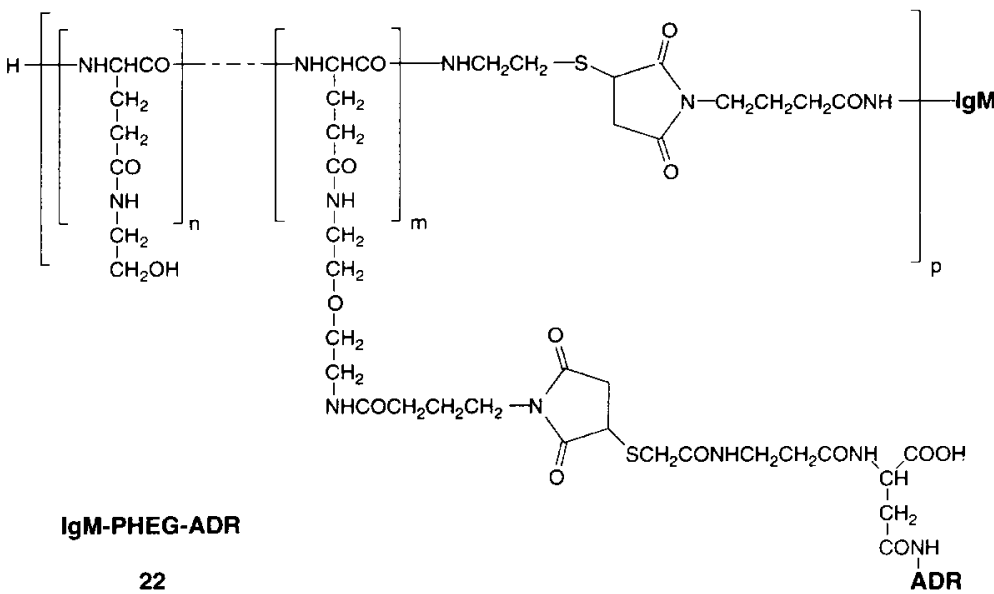

Fig. 6. Structure of immunoconjugate IgM-PHEG-ADR 22 prepared from IgM and $\mathrm{S}_{2}$-PHEG-ADR 19a,b.

was observed as shown by HP-SEC analysis on Zorbax GF-450 (Fig. 8).

The immunoconjugate was fractionated by gel filtration on TSK Fraktogel HW-55S (Fig. 9). The IgMPHEG-ADR conjugate 22 elutes before either free IgM or 19a,b as shown by calibration of the column. This result is similar to what is observed for IgM-PGA and IgM-PHEG conjugates and is expected on the basis of the increased molecular weight [10]. Thus, fractions 23 and 24 were pooled to yield immunoconjugate with a negligible amount of free IgM. The combined fractions represent $67 \%$ recovery of protein.

IgM-PGA and IgM-PHEG conjugates studied previously have been purified by gel filtration of Fraktogel HW-55S [10]. Despite careful pooling, free polymers were present in the immunoconjugates probably due to complex formation between the immunoconjugates and free polymers [10]. Removal of unreacted 19a,b from immunoconjugates remaining after gel filtration could be accomplished by anion-exchange chromatography ( $\mathrm{AEC}$ ) on Q-Sepharose Fast Flow using elution with a stepwise salt gradient (Fig. 10). Conjugate 19a,b is almost completely desorbed by elution with buffers containing up to $150 \mathrm{mM} \mathrm{NaCl}$. Under these conditions IgM 16.88 and 22 remain bound and are desorbed by increasing the salt concentration to 250 $300 \mathrm{mM}$ and $200-250 \mathrm{mM}$, respectively. By this method the remaining amount of $19 \mathbf{a}, \mathbf{b}$ was removed from the immunoconjugate-containing fractions 23 and 24 from Fraktogel HW-55S (Fig. 11). The immunoconjugate fraction eluted by $250 \mathrm{mM} \mathrm{NaCl}$ was concentrated by ultrafiltration and sterilized by filtration through a $0.20 \mu \mathrm{m}$ filter. The solution thus obtained was used for biodistribution experiments.

The fractions containing immunoconjugate from SEC and AEC were analysed by SDS-PAGE per-

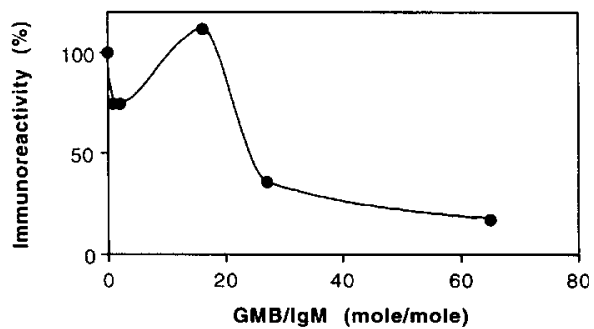

Fig. 7. Effect of introduction of $N$ - ( $\gamma$-maleimidobutyryloxy $)$ groups onto IgM 16.88 on immunoreactivity. 

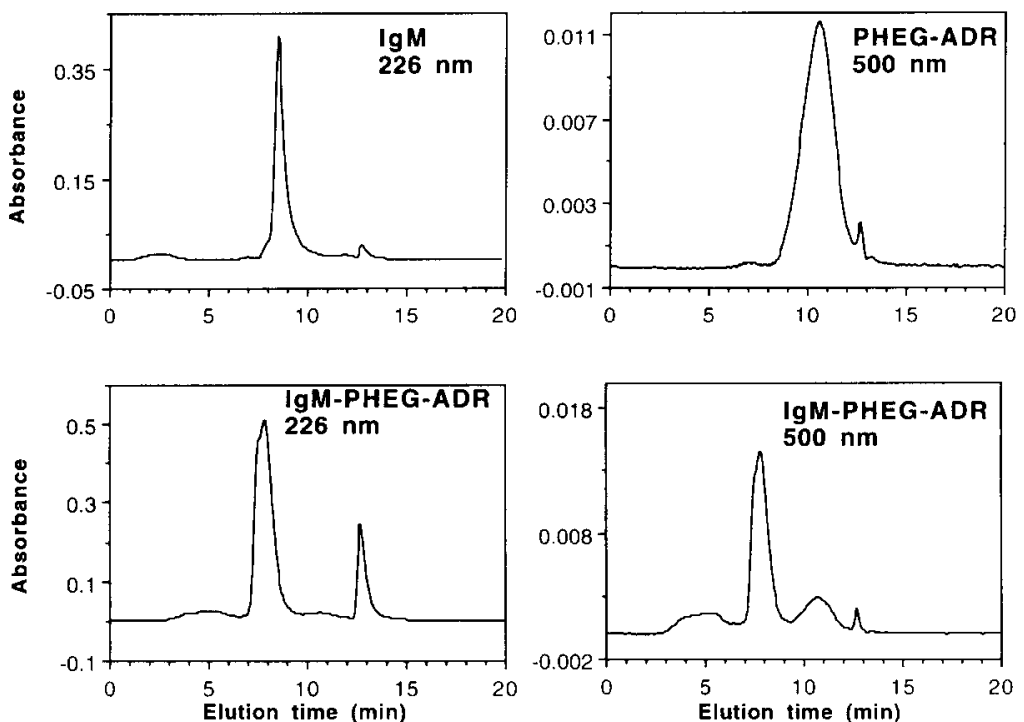

Fig. 8. HP-SEC on Zorbax GF-450 $(300 \times 7.8 \mathrm{~mm})$ in $0.20 \mathrm{M}$ sodium phosphate, $\mathrm{pH} 7.0$ at a flow rate of $1.0 \mathrm{ml} / \mathrm{min}$. Samples: IgM $16.88, \mathrm{~S}_{2}$ PHEG-ADR 19a,b and immunoconjugate 22 prepared from IgM 16.88 and reduced 19a,b (crude reaction mixture).

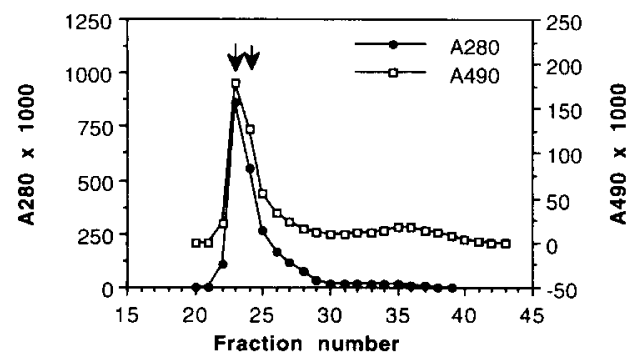

Fig. 9. Preparative SEC on Fraktogel TSK HW-55S $(80 \times 2.6 \mathrm{~cm}$, $425 \mathrm{ml}$ ) in buffer IV at a flow rate of $40 \mathrm{ml} / \mathrm{h}$. Sample: immunoconjugate 22 prepared from $\operatorname{IgM} 16.88$ and reduced $\mathrm{S}_{2}$-PHEG-ADR 19a,b (crude reaction mixture). The fractions ( $5.4 \mathrm{ml}$ each) were pooled as indicated by the arrows.

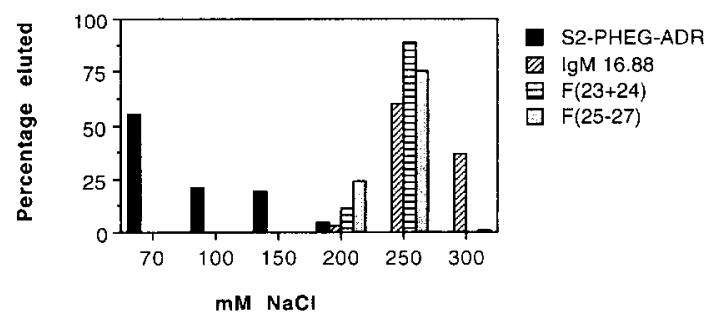

Fig. 10. Percentage recovery in AEC on Q-Sepharose FF $(12 \times 1.6$ $\mathrm{cm}, 24 \mathrm{ml}$ ) equilibrated in $25 \mathrm{mM}$ Tris $\cdot \mathrm{HCl}, \mathrm{pH} 8.0$, buffer containing $70 \mathrm{mM} \mathrm{NaCl}$. Samples: $S_{2}$-PHEG-ADR 19a,b, IgM and immunoconjugate 22 fractions obtained after SEC on Fraktogel HW-55S (Fig. 9). The samples were applied in the equilibration buffer and stepwise elution was performed with $25 \mathrm{mM}$ Tris $\cdot \mathrm{HCl}$ buffer, $\mathrm{pH}$ 8.0 containing $70-300 \mathrm{mM} \mathrm{NaCl}$. formed under non-reducing and reducing conditions and Western blots on PVDF membranes were prepared (Fig. 12). SDS-PAGE under non-reducing conditions of fractions ( 23,25 and 28 ) obtained after gel filtration on Fraktogel HW-55S indicates the presence of immunoconjugate, which hardly penetrates the stacking gel. $\operatorname{IgM}$ is absent in fraction 23 but trace amounts of IgM are present in the later fractions. The immunoconjugate end product obtained after anion-exchange chromatography of the pooled fractions 23 and 24 on Q-Sepharose shows again the absence of IgM. Under reducing conditions the immunoconjugate fractions as well as

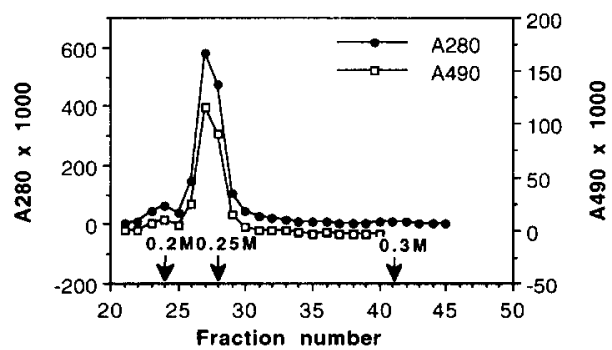

Fig. 11. Preparative AEC on Q-Sepharose FF $(12 \times 1.6 \mathrm{~cm}, 24 \mathrm{ml})$ equilibrated in $25 \mathrm{mM}$ Tris $\cdot \mathrm{HCl}, \mathrm{pH} 8.0$, buffer containing $70 \mathrm{mM}$ $\mathrm{NaCl}$. Sample: combined fractions 23 and 24 containing IgM-PHEGADR immunoconjugate 22 after SEC on Fraktogel HW-55S (Fig. 9). The sample was applied in the equilibration buffer and stepwise elution was performed with $25 \mathrm{mM}$ Tris $\cdot \mathrm{HCl}$ buffer, $\mathrm{pH} 8.0$ containing $70-300 \mathrm{mM} \mathrm{NaCl}$. 
A

\section{SDS- WESTERN PAGE BLOT}

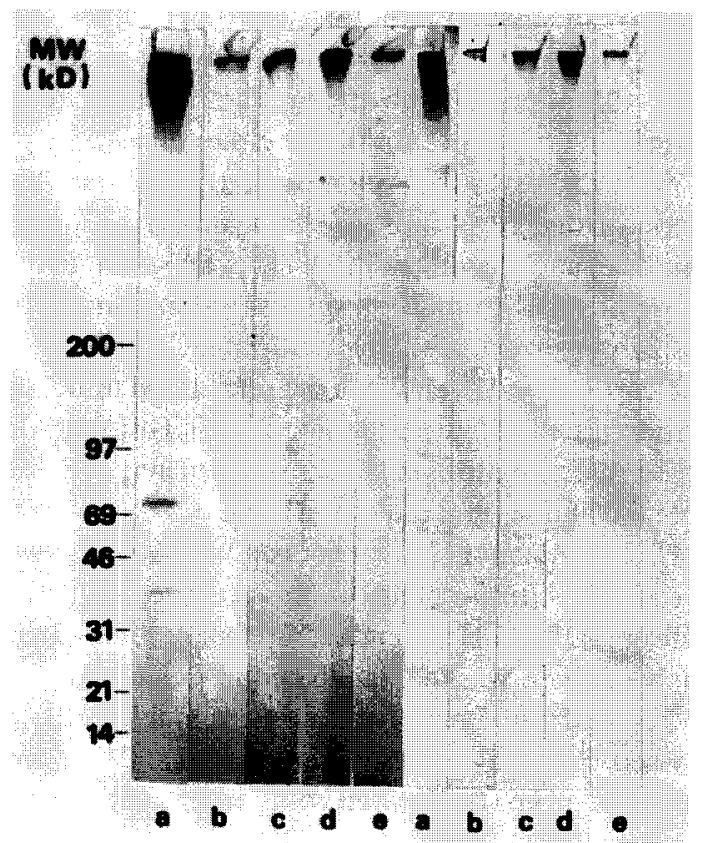

B

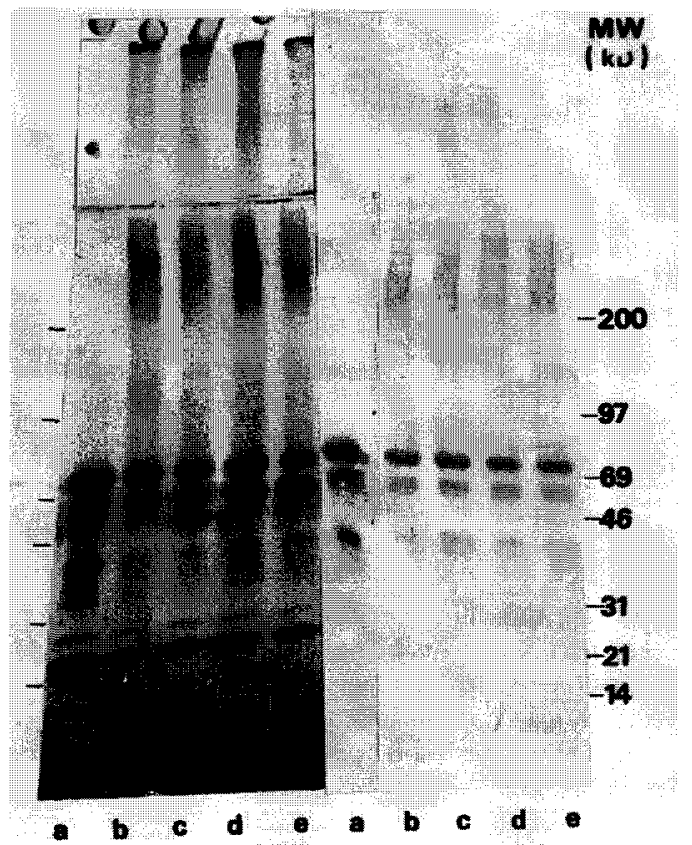

Fig. 12. SDS-PAGE under non-reducing (A) and reducing conditions (B) of IgM 16.88 (a), IgM-PHEG-ADR 22 after SEC on Fraktogel HW$55 S$, fraction 23 (b), fraction 25 (c) and fraction 28 (d), and 22 after AEC on Q-Sepharose by desorption with $0.25 \mathrm{M} \mathrm{NaCl-containing} \mathrm{buffer}$ (e). The proteins were stained by Serva Blue G-250 (gels) and DAB after treatment with HRP-linked goat anti-human IgM (Western blots).

IgM show discrete bands at $86 \mathrm{kDa}$ (heavy chain), 70 $\mathrm{kDa}$ ( $\mathrm{J}$ chain complex) and $28 \mathrm{kDa}$ (light chain). In addition, the immunoconjugates show very diffuse bands extending across the gel which represent conjugates of the various chains with PHEG-ADR. The diffuse character of the bands is due to the polydisperse nature of the polymer-protein conjugates with respect to degree of substitution by PHEG-ADR and polymer molecular weight. Unsubstituted protein chains after reduction of IgM-PHEG-ADR are present because each mole of IgM has 10 heavy and 10 light chains and the average degree of substitution, assuming random coupling, is about 14 mol PHEG-ADR per mol of IgM or 0.7 mol PHEG-ADR per chain.

\subsection{Immunoreactivity of IgM-PHEG-ADR 22}

Fractions containing IgM-PHEG-ADR 22 were assessed for immunoreactivity by solid-phase EIA using HRP-linked goat anti-human IgM (Fig. 13, Table 3). To evaluate the titer of the immunoconjugates with respect to CTA-1 binding, the data on the active immunoreactivity involving assay of immunoconjugate bound to antigen precoated onto the solid phase had to be corrected for the altered binding between immunoconjugate and HRP-linked goat antihuman IgM. Analysis of the passive immunoreactivity by assay of immunoconjugate precoated onto the solid phase shows that binding of HRP-linked goat antihuman IgM is slightly weakened in comparison with IgM. This may be rationalized by a minor steric hindrance of the binding site of second antibody mediated by IgM-bound PHEG-ADR chains. The antigenrelated titer values show that the immunoreactivity of 22 is preserved to a large extent compared that of IgM 16.88 . 

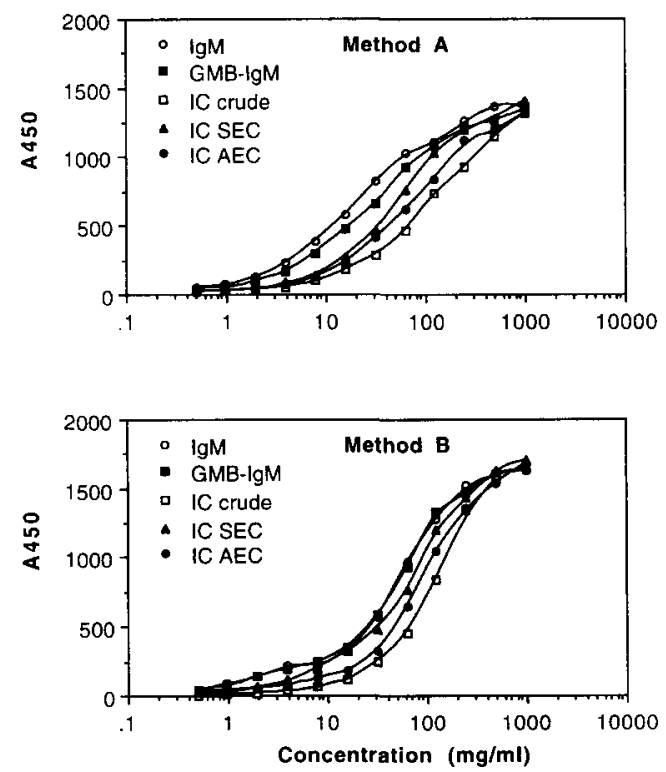

Fig. 13. Titration curves of immunoconjugate (IC) IgM-PHEGADR 22 fractions determined by solid-phase enzyme immunoassay using HRP-linked goat anti-human IgM. Method A (active immunoreactivity), assay of immunoconjugate bound to CTA-1 precoated onto solid-phase; method B (passive immunoreactivity), assay of immunoconjugate precoated onto solid-phase.

Table 3

Titers (\%) of IgM-PHEG-ADR 22 fractions determined by solidphase enzyme immunoassay using HRP-linked goat anti-human IgM

\begin{tabular}{|c|c|c|c|}
\hline \multirow[t]{2}{*}{ Compound } & \multicolumn{3}{|l|}{ Titer $(\%)$} \\
\hline & Method A & Method B & Antigen-related \\
\hline$-\operatorname{IgM}$ & 100 & 100 & 100 \\
\hline 21 GMB-IgM $^{\mathrm{a}}$ & 67 & 100 & 67 \\
\hline 22 IgM-PHEG-ADR crude & 20 & 44 & 45 \\
\hline $\begin{array}{l}22 \text { IgM-PHEG-ADR after } \\
\text { SEC }^{\text {h }}\end{array}$ & 44 & 70 & 63 \\
\hline $\begin{array}{l}22 \text { IgM-PHEG-ADR after } \\
\text { AEC }^{c}\end{array}$ & 29 & 54 & 54 \\
\hline
\end{tabular}

Method A (active immunoreactivity), titer found after assay of immunoconjugate bound to CTA-1 precoated onto solid-phase; method B (passive immunoreactivity), titer found after assay of immunoconjugate precoated onto solid-phase; antigen-related, titer pertinent to antigen binding.

"18 mol of GMB groups per mol of IgM.

${ }^{b}$ Fraction 23 obtained after gel filtration on Fraktogel HW-55S (Fig. 9).

'fraction obtained after AEC on Q-Sepharose Fast Flow by desorption with $0.25 \mathrm{M} \mathrm{NaCl}$-containing buffer (Fig. 11) and used for biodistribution studies.

\subsection{In vitro drug release and cytotoxicity}

The in vitro release rate of ADR from PHEG-ADR 20 having an acid-labile drug-carrier bond was determined by incubation in buffer at two $\mathrm{pH}$ values using ADR as a control (Fig. 14). The stability of the free drug is limited as shown by the time-dependent decrease in drug concentration at either $\mathrm{pH} 6.0\left(t_{1 / 2} 11\right.$ h) or $\mathrm{pH} 7.5\left(t_{1 / 2} 7 \mathrm{~h}\right)$. Any measured amount of ADR released from 20 is thus due to hydrolysis from the conjugate and decomposition. The apparent rate of release of ADR from $\mathbf{2 0}$ is significant only at $\mathrm{pH}$ 6.0. This is consistent with the acid-labile nature of the drug-carrier bond even when the rates of ADR decomposition are taken into account. The half-life of ADR release due to hydrolysis of $\mathbf{2 0}$ is estimated at $8-10 \mathrm{~h}$ at $\mathrm{pH} 6.0$ and several days at $\mathrm{pH} 7.5$.

HT-29 human colon adenocarcinoma cells were grown in microtitre plates in the presence of PHEGADR or ADR at pH 6.0 and 7.5 up to day 1, 3 or 5. The cells were then washed, incubated in fresh medium at pH 7.5 until day 7 and the number of viable cells was assessed (Fig. 15). These data show that $\mathbf{2 0}$ is more effective at $\mathrm{pH} 6.0$ compared with $\mathrm{pH} 7.5$ in accordance with the rates of ADR release.

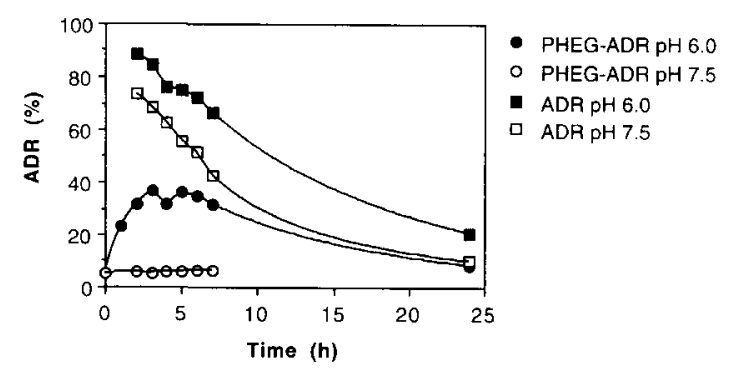

Fig. 14. Release of ADR from PHEG-ADR 20 conjugate in sodium phosphate buffer, $\mathrm{pH} 6.0$ or 7.5 , at $37^{\circ} \mathrm{C}$. ADR was used as the control.

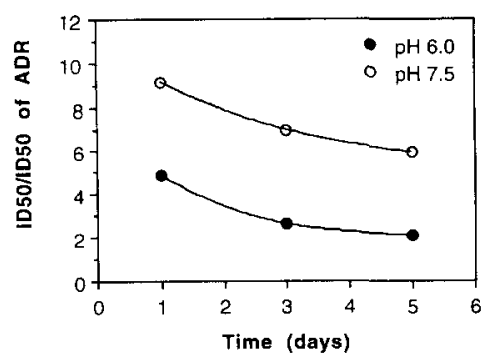

Fig. 15. Inhibition of growth of HT-29 human colon adenocarcinoma cells by ADR and PHEG-ADR 20 containing an acid-labile drugcarrier bond. 

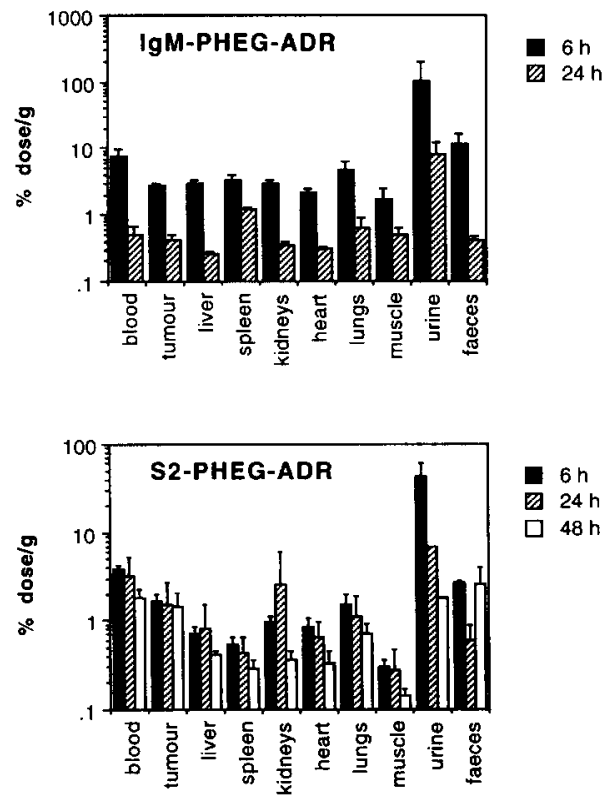

Fig. 16. Biodistribution of ${ }^{131} \mathrm{I}$ bound to IgM-PHEG-ADR 22 and of ${ }^{125} \mathrm{i}$ bound to $S_{2}$-PHEG-ADR 19a,b in mice carrying subcutaneously implanted MRI-H-207 human ovarian tumour xenografts.

3.8. Biodistribution and tumour uptake of ${ }^{I 3 I} I$ labelled IgM-PHEG-ADR 22, ${ }^{125}$ I-labelled $S_{2}-P H E G$ ADR $19 a, b$ and ${ }^{3} H$-labelled IgM 16.88

The blood level, tumour uptake and biodistribution of ${ }^{131}$ I-labelled IgM-PHEG-ADR 22, which was coadministered with ${ }^{3} \mathrm{H}$-labelled IgM 16.88 , and of ${ }^{125} \mathrm{I}$ labelled $\mathrm{S}_{2}$-PHEG-ADR 19a,b in nude mice carrying MRI-H-207 human ovarian tumour xenografts were studied at 6, 24 and $48 \mathrm{~h}$ after administration (Fig. 16 and Fig. 17). ${ }^{125}$ I bound to 19 a,b shows a slower blood clearance as compared to IgM with minimal uptake in organs like liver, spleen and heart. The level of tumour uptake of ${ }^{125} \mathrm{I}$ bound to $19 \mathrm{a}, \mathrm{b}$ is constant over $48 \mathrm{~h}$, which means a corresponding increase in the tumourto-blood ratio and is an indication of passive tumour targeting. The blood clearance and tumour uptake change completely upon administration of immunoconjugate. ${ }^{131} \mathrm{I}$ bound to $\mathbf{2 2}$ shows a significant blood level at $6 \mathrm{~h}$ but is cleared more rapidly than ${ }^{3} \mathrm{H}$ bound to the unmodified antibody with relatively low uptake of the label in liver, kidneys and spleen. ${ }^{131} \mathrm{I}$ bound to immunoconjugate is taken up appreciably by the tumour at $6 \mathrm{~h}$ but disappeared more rapidly than $\mathrm{IgM}$. At $48 \mathrm{~h}$ only very low amounts of ${ }^{131} \mathrm{I}$ in either blood or
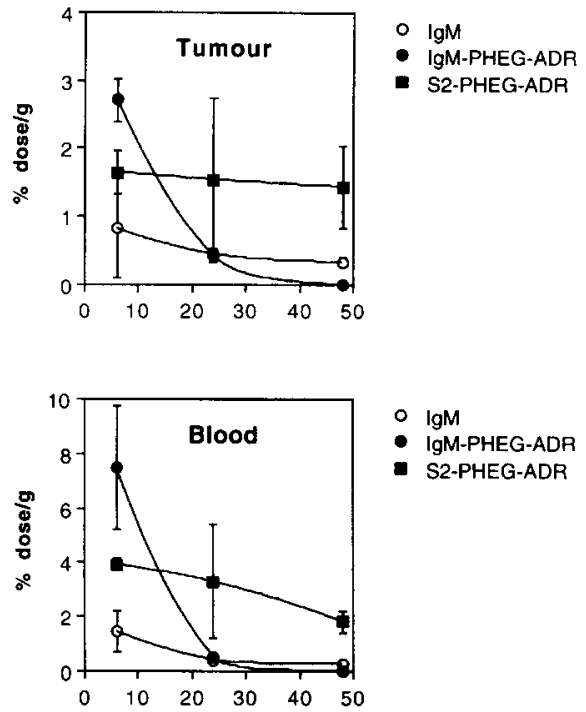

- $\lg M$

- IgM-PHEG-ADR

- S2-PHEG-ADR

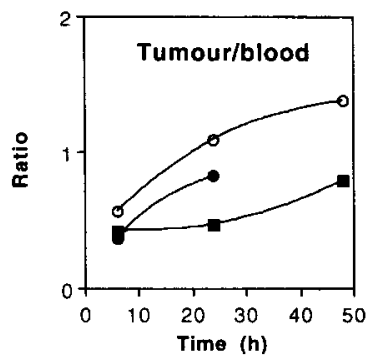

- $\lg M$

- IgM-PHEG-ADR

- S2-PHEG-ADR

Fig. 17. Time dependence of tumour uptake and blood concentration of ${ }^{131} \mathrm{I}$ bound to IgM-PHEG-ADR 22, of ${ }^{3} \mathrm{H}$ bound to IgM 16.88 and of ${ }^{125} \mathrm{I}$ bound to $\mathrm{S}_{2}$-PHEG-ADR 19a,b in mice carrying subcutaneously implanted MRI-H-207 human ovarian tumour xenografts.

tissues were detected (data not shown) suggesting the almost complete absence of $\mathbf{2 2}$. The tumour-to-blood ratio of ${ }^{3} \mathrm{H}$-labelled IgM increases in the period from 6 to $48 \mathrm{~h}$ indicating slow kinetics of the antibody in penetrating the tumour. The tumour-to-blood ratio of ${ }^{131} \mathrm{I}$ bound to 22 shows similar behaviour from 6 to $24 \mathrm{~h}$ but at $48 \mathrm{~h}$ no significant value could be estimated due to the small amount of the label in both the blood and the tumour. It is concluded that the residence time of the immunoconjugate in the blood is too short to allow effective tumour targeting of drug.

\section{Discussion}

In order to deliver a therapeutically effective dose of cytostatic drugs to the tumour with IgM 16.88, which 
is highly susceptible to chemical modification, we employed an intermediate drug carrier for which PGA and the neutral derivative PHEG were possible candidates. In order to test the applicability of these polymers in targeted drug therapy, immunoconjugates of human IgM 16.88 and PGA or PHEG were synthesized and purified and subjected to a biodistribution study [10]. The biodistribution of either IgM-PGA or IgM-PHEG was identical with that of the IgM proper and we have concluded that the polyanion PGA and the uncharged derivative PHEG are equally suitable as drug carriers in immunoconjugates. Removal of unbound polymers from the immunoconjugates by gel filtration was incomplete probably due to complex formation. For this reason we decided to use PHEG as the carrier because purification of immunoconjugates by other methods, notably anion- or cation exchange chromatography, is facilitated by the uncharged character of PHEG.

The release of free drug from carrier-drug conjugates by chemical hydrolysis at acid $\mathrm{pH}$, which occurs for instance in endosomes and lysosomes of cells, can be accomplished by using the acid-labile cis-aconityl linkers introduced by Shen and Ryser [34]. We have prepared improved linkers allowing unequivocal binding of drug and carrier $[11,12,20]$. The linkers contain a drug moiety bound either through an acid-labile or a hydrolytically stable bond which is useful for control studies as well as an acetyl-protected thiol function for conjugation to carriers. The rate of acid-catalyzed release of ADR is dependent on the size of the $\beta$ substituent at the double bond of the drug linkage (data not shown). PHEG-ADR conjugate containing the acid-labile ADR derivative shows a significant release of ADR upon incubation in buffer solution at pH 6.0. Furthermore, ADR is released in cytotoxic amounts when HT-29 human colon adenocarcinoma cells are cultured in the presence of conjugate at $\mathrm{pH} 6.0$ and to a lesser extent also at $\mathrm{pH} 7.5$. In principle, the release of drug can be extracellular in the acidic environment of the tumour or intracellular, catalyzed by the acidic environment of endosomes and lysosomes, after pinocytosis of the conjugate by the cells. The enhanced cytotoxicity of PHEG-ADR at $\mathrm{pH} 6.0$ as compared to $\mathrm{pH} 7.5$ suggests that at $\mathrm{pH} 6.0$ a major part of the drug is released extracellularly. The results indicate that extracellular drug release from PHEG-bound ADR in an acidic environment could be therapeutically effec- tive provided that the residence time of the conjugate is sufficiently long.

In order to bind the ADR derivatives and IgM to PHEG independently, the drug carrier having thiol groups for coupling with protein was modified by introduction of amine groups. This was accomplished by a multistep procedure starting from PGA containing thiol end groups. The coupling of the ADR derivative with PHEG and of IgM with PHEG-ADR were both effected by the use of a heterobifunctional coupling agent containing an activated ester and a maleimido group yielding an amide bond and a thioether bond, respectively. The extent of immunoconjugate formation was improved compared with our previous study [10]. The immunoreactivity of the immunoconjugate was almost fully preserved indicating that the antigen binding site was not denatured or sterically shielded by PHEGADR to a significant extent. From the data the number of drug molecules carried by one molecule of immunoconjugate is estimated at 65 . The amount of free PHEG-ADR in the immunoconjugate is estimated to be low or very low due to the improved method of purification. The absence of free $\operatorname{IgM}$ allowed us to study the biodistribution of the immunoconjugate through the ${ }^{131}$ I label of the antibody.

To study the biodistribution and tumour uptake of IgM-PHEG-ADR and PHEG-ADR we have used the MRI-H-207 human ovarian tumour xenograft subcutaneously implanted in nude mice [22]. The MRI-H-207/nude mice system is an appropriate solidtumour model for ADR-containing conjugates of IgM 16.88 due to the sensitivity of the tumour to ADR, the presence of specific antigen and the extent of vascularization. The prolonged residence time of PHEG-ADR in the tumour and in the circulation enhances the prospect of PHEG conjugate containing the acid-labile ADR derivative for effective therapy as discussed above. The residence time of IgM-PHEG-ADR in blood as well as in MRI-H-207 human ovarian tumours proved to be significantly shorter than that of IgM. These results are in contrast with earlier data on the biodistribution of an immunoconjugate of IgM 16.88 and PHEG which was indistinguishable from that of unmodified IgM [10]. Results very similar to those on IgM-PHEG-ADR were obtained with immunoconjugates of IgM and either directly bound ADR or human serum albumin-bound ADR (E.S. Bos, unpublished data). Apparently, the presence of ADR in the immu- 
noconjugates alters the physicochemical properties in such a way that the conjugate becomes prone to rapid clearance with a concomitant decrease in tumour uptake. On the basis of the present results with the IgMPHEG-ADR immunoconjugate having a hydrolytically stable drug bond it is concluded that therapeutically effective drug targeting with immunoconjugates of IgM 16.88 and ADR is not practical in this tumour model. A major improvement may be possible by the design of drug carriers which suppress undesired interactions of ADR under in vivo conditions.

\section{Conclusions}

(1) Conjugates of PHEG and ADR with either an acid-labile or a hydrolytically stable drug-carrier bond have been prepared by a multistep procedure. (2) Release of drug in cytotoxic amounts from PHEGbound ADR having an acid-labile drug-carrier bond is effected in vitro by using a slightly acidic culture medium. (3) Immunoconjugates of high purity and immunoreactivity have been obtained from IgM 16.88 and PHEG-ADR. (4) Targeting of ADR in a solid tumour model in mice with an IgM-PHEG-ADR immunoconjugate appears not to be practical probably due to biodistribution effects mediated by the bound drug. (5) PHEG-ADR shows passive targeting in a solid tumour model in mice due to a prolonged residence time in the circulation.

\section{Acknowledgements}

This work has been supported by the Ministry of Economic Affairs of The Netherlands. We thank Dr. J.W.A. van den Berg for critical reading of the manuscript and Mr. C.J. Padberg for support in the polymer analyses.

\section{References}

[1] E.S. Bos, P. Boon, F. Kaspersen and R. McCabe, Passive immunotherapy of cancer: perspectives and problems, J. Control. Release 16 ( 1991) 101-112.

[2] For a survey, see Abstracts from the Sixth International Conference on Monoclonal Antibody Immunoconjugates for Cancer, February 27-March 2, 1991, San Diego, USA, Antibody, Immunoconj. Radiopharm. (1991) 201-239.
[3] Y. Kato, N. Umemoto, Y. Kayama, H. Fukushima, Y. Takeda, T. Hara and Y. Tsukada, A novel method of conjugation of daunomycin with antibody with a poly-L-glutamic acid derivative as intermediate drug carrier. An anti- $\alpha$-fetoprotein antibody-daunomycin conjugate, J. Med. Chem. 27 (1984) 1602-1607.

[4] R.G. Steis, J.A. Carrasquillo, R.P. McCabe, M.A. Bookman, J.C. Reynolds, S. Larson, J.W. Smith, J.W. Clark, V. Dailey, S. Del Vecchio, N. Shuke, C.M. Pinsky, W.J. Urba, M. Haspel, P. Perentesis, B. Paris, D.L. Longo and M.G. Hanna Jr., Toxicity, immunogenicity and tumour radioimmunodetecting ability of two human monoclonal antibodies in patients with metastatic colorectal carcinoma, J. Clin. Oncol. 8 (1990) 476 490.

[5] H.J. Haisma, M.A.P. Kessel, C. Silva, M. van Muijen, J.C. Roos, H. Bril, H.J.M. Martens, R. McCabe and E. Boven, Human IgM monoclonal antibody 16.88: pharmacokinetics and distribution in mouse and man, Br. J. Cancer 62, Suppl. X (1990) 40-43.

[6] E. Boven, H.J. Haisma, H. Bril, H.J.M. Martens, A. van Lingen, W. den Hollander, M.A.P. Kessel, R. De Jager and J.C. Roos, Tumour localisation with ${ }^{1.31}$ l-labelled human IgM monoclonal antibody 16.88 in advanced colorectal cancer patients, Eur. J. Cancer 27 (1991) 1430-1436.

[7] R. De Jager, H. Abde]-Nabi, A. Serafini, A. Pecking, J.L. Klein and M.G. Hanna Jr, Current status of cancer immunodetection with radiolabeled human monoclonal antibodies, Sem. Nucl. Med. 23 (1993) 165-179.

[8] N. Pomato, J.H. Murray, E. Bos, M.V. Haspel, R.P. McCabe and M.G. Hanna, Identification and characterization of a human colon tumor-associated antigen, CTAA 16-88, recognized by a human monoclonal antibody, in: R.S. Metzger and M.S. Mitchell (Eds), Human Tumor Antigens and Specific Tumor Therapy, A.R. Liss, New York, 1989, pp. 127-136.

[9] C.J.T. Hoes and J. Feijen, The application of drug-polymer conjugates in chemotherapy, in: F.H.D. Roerdink and A.M. Kroon (Eds), Drug Carrier Systems, Wiley \& Sons Ltd., Chichester, 1989, pp. 57-109.

[10] C.J.T. Hoes, J. Grootoonk, J. Feijen, P.J. Boon, F. Kaspersen, P. Loeffen, I. Schlachter, M. Winters and E.S. Bos, Synthesis and biodistribution of immunoconjugates of a human IgM and polymeric drug carriers, J. Control. Release 19 ( 1992) 59-76.

[11] European Patent 495265; US Patent 5306809.

[12] P. Boon, E. Bos, F. Kaspersen, A. de Man, A. van Ettekoven, P. Loeffen, D. Pham and R. McCabe, Novel, acid sensitive linker structures: design, synthesis and application in the preparation of adriamycin immunoconjugates, Antibody, Immunoconj. Radiopharm. 5 ( 1992) 118.

[13] St. Guttmann and R.A. Boissonnas, Synthèse du $N$-acétyl-Lséryl-L-tyrosyl-L-séryl-L-méthionyl- $\gamma$-L-glutama te de benzyle et des peptides apparantés, Helv. Chim. Acta 41 (1958) 1852.

[14] C.J.T. Hoes, J. Grootoonk, R. Duncan, I.C. Hume, M. Bhakoo, J.M.W. Bouma and J. Feijen, Biological properties of adriamycin bound to biodegradable polymeric carriers, J. Control. Release 23 ( 1993 ) 37-54. 
[15] J. Barnett, Analogs of pantothenic acid. III. Preparation of growth-inhibiting analogs related to $N$-pantoyltaurine, J. Chem. Soc. (1944) 5-8.

[16] G.L. Ellman, Tissue sulfhydryl groups, Arch. Biochem. Biophys. 82 ( 1959) 70-77.

[17] D.R. Grassetti and J.F. Murray, Determination of sulfhydryl groups with 2,2'- or 4,4'-dithiopyridine, Arch. Biochem. Biophys. 119 ( 1967 ) 41-49.

[18] H. Towbin, T. Shaehelin and J. Gordon, Electrophoretic transfer of proteins from polyacrylamide gels to nitrocellulose sheets: procedures and some applications, Proc. Natl. Acad. Sci. USA 76 ( 1979 ) 4350-4354.

[19] P.G. Mattingly, Mono-protected diamines. $N^{\alpha}$-tertButoxycarbonyl $\alpha, \omega$-alkanediamine hydrochlorides from amino alcohols, Synthesis April (1990) 366-368.

[20] P.J. Boon et al., in preparation.

[21] D.A. Scudiero, R.H. Shoemaker, K.D. Paull, A. Monks, S. Tierney, T.H. Nofziger, M.J. Currens, D. Seniff and M.R. Boyd, Evaluation of a soluble tetrazolium/formazan assay for cell growth and drug sensitivity in culture using human and other tumor cell lines, Cancer Res. 48 ( 1988 ) $4827-4833$

[22] E. Boven, Human ovarian cancer xenografts in nude mice. Application of a new model in the selection of novel agents for ovarian cancer, Ph.D. thesis, Free University of Amsterdam. 1986.

[23] K. Nilsson, O. Norrlöw and K. Mosbach, p-Toluenesulfonyl chloride as an activating agent of agarose for the preparation of immobilized affinity ligands and proteins. Optimization of conditions for activation and coupling, Acta Chem. Scand. B 35 ( 1981 ) 19-27.

[24] K. Nilsson and K. Mosbach, Immobilization of ligands wirh organic sulfonyl chlorides, Methods Enzymol. 104 ( 1984 ) 5669.

[25] A. Lääne, M. Haga, A. Aaviksaar, V. Chytry and J. Kopecek, Activation of poly [ $\mathrm{N}$-(2-hydroxypropyl) methacrylamide] for the binding of bioactive molecules. I, Makromol. Chem. 184 ( 1983 ) 1339-1344.
[26] E. Schacht, J. Vermeersch, F. Vandoorne, R. Vercauteren and J.P. Remon, Synthesis and characterization of some modified polysaccharides containing drug moieties, J. Control. Release 2 (1985) 245-256.

[27] W.A.R. van Heeswijk, C.J.T. Hoes, T. Stoffer, M.J.D. Eenink, W. Potman and J. Feijen, The synthesis and characterization of polypeptide-adriamycin conjugates and its complexes with adriamycin. I, J. Control. Release 1 ( 1985) 301-315.

[28] J. Gerber and H.G. Elias, Multimerisation: Association and aggregation. VII. Poly- $\gamma$-benzyl-L-glutamat in reinen Lösungsmitteln, Makromol. Chem. 112 ( 1968) 142-159.

[29] W. Bushuk and H. Benoit, Light-scattering studies of copolymers. I. Effect of heterogeneity of chain composition on the molecular weight, Can. J. Chem. 36 (1958) 1616-1626.

[30] H. Tanimori, T. Kitagawa, T. Tsunoda and R. Tsuchiya, Enzyme immunoassay of neocarzinostatin using $\beta$ galactosidase as a label, J. Pharm. Dyn. 4 ( 1981 ) 812-819.

[31] M.D. Partis, D.G. Griffiths, G.C. Roberts and R.B. Beechey, Cross-linking of protein by $\omega$-maleimido alkanoyl $\mathrm{N}$ hydroxysuccinimido esters, J. Protein Chem. 2 ( 1983) 263277.

[32] S. Yoshitake, M. Imagawa, E. Ishikawa, Y. Niitsu, I. Urushizaki, M. Nishiura, R. Kanazawa, H. Kurosaki, S. Tachibana, N. Nakazawa and H. Ogawa, Mild and efficient conjugation of rabbit $\mathrm{Fab}^{\prime}$ and horseradish peroxidase using a maleimide compound and its use for enzyme immunoassay, $\mathbf{J}$. Biochem. 92 (1982) 1413-1424.

[33] M. Nukui, K. Hoes, H. van den Berg and J. Feijen, Association of macromolecular prodrugs consisting of adriamycin bound to poly(L-glutamic acid), Makromol. Chem. 192 (1991) $2925-2942$.

[34] W.-C. Shen and H.J.-P. Ryser, cis-Aconityl spacer between daunomycin and macromolecular carriers: a model of $\mathrm{pH}$ sensitive linkage releasing drug from a lysosomotropic conjugate, Biochem. Biophys. Res. Commun. 102 (1981) 1048-1054. 